OPEN ACCESS

Edited by:

Mirko Paiardini,

Emory University School of Medicine,

United States

Reviewed by:

Paul Goepfert,

University of Alabama at Birmingham,

United States

Kristina De Paris,

University of North Carolina at

Chapel Hill, United States

*Correspondence:

Bruce D. Walker

bwalker@mgh.harvard.edu

†These authors have contributed equally to this work

Specialty section

This article was submitted to

Viral Immunology,

a section of the journal

Frontiers in Immunology

Received: 21 June 2019

Accepted: 21 August 2019

Published: 10 September 2019

Citation:

Mylvaganam G, Yanez AG, Maus M and Walker BD (2019) Toward T Cell-Mediated Control or Elimination of HIV Reservoirs: Lessons From

Cancer Immunology.

Front. Immunol. 10:2109.

doi: 10.3389/fimmu.2019.02109

\section{Toward T Cell-Mediated Control or Elimination of HIV Reservoirs: Lessons From Cancer Immunology}

\author{
Geetha Mylvaganam ${ }^{1 \dagger}$, Adrienne G. Yanez ${ }^{1 \dagger}$, Marcela Maus ${ }^{1,2}$ and Bruce D. Walker ${ }^{1,3,4 *}$ \\ ${ }^{1}$ Ragon Institute of MGH, MIT and Harvard, Cambridge, MA, United States, ${ }^{2}$ MGH Cancer Center, Boston, MA, \\ United States, ${ }^{3}$ Howard Hughes Medical Institute, Chevy Chase, MD, United States, ${ }^{4}$ Institute for Medical Engineering and \\ Sciences, MIT, Cambridge, MA, United States
}

As the AIDS epidemic unfolded, the appearance of opportunistic infections in at-risk persons provided clues to the underlying problem: a dramatic defect in cell-mediated immunity associated with infection and depletion of $\mathrm{CD}^{+}{ }^{+} \mathrm{T}$ lymphocytes. Moreover, the emergence of HIV-associated malignancies in these same individuals was a clear indication of the significant role effective cellular immunity plays in combating cancers. As research in the HIV field progressed, advances included the first demonstration of the role of PD-1 in human T cell exhaustion, and the development of gene-modified $\mathrm{T}$ cell therapies, including chimeric antigen receptor (CAR) T cells. In the intervening years, the oncology field has capitalized on these advances, effectively mobilizing the cellular immune response to achieve immune-mediated remission or cure of previously intractable cancers. Although similar therapeutic advances have not yet been achieved in the HIV field, spontaneous $\mathrm{CD}^{+} \mathrm{T}$ cell mediated remission or functional cure of HIV infection does occur in very small subset of individuals in the absence of anti-retroviral therapy (ART). This has many similarities to the $\mathrm{CD}^{+} \mathrm{T}$ cell mediated functional control or elimination of cancers, and indicates that immunotherapy for HIV is a rational goal. In HIV infection, one major barrier to successful immunotherapy is the small, persistent population of infected $\mathrm{CD} 4^{+} \mathrm{T}$ cells, the viral reservoir, which evades pharmacological and immune-mediated clearance, and is largely maintained in secondary lymphoid tissues at sites where $\mathrm{CD}^{+} \mathrm{T}$ cells have limited access and/or function. The reservoir-enriched lymphoid microenvironment bears a striking resemblance to the tumor microenvironment of many solid tumors-namely high levels of anti-inflammatory cytokines, expression of co-inhibitory receptors, and physical exclusion of immune effector cells. Here, we review the parallels between $\mathrm{CD}^{+} \mathrm{T}$ cell-mediated immune control of HIV and cancer, and how advances in cancer immunotherapy may provide insights to direct the development of effective HIV cure strategies. Specifically, understanding the impact of the tissue microenvironment on $\mathrm{T}$ cell function and development of CAR T cells and therapeutic vaccines deserve robust attention on the path toward a CD8 ${ }^{+} \mathrm{T}$ cell mediated cure of HIV infection.

\footnotetext{
Keywords: HIV, cancer, remission, CTL (cytotoxic T lymphocyte), immunothearpy
} 


\section{INTRODUCTION}

Human immunodeficiency virus (HIV) remains one of the most pervasive global health challenges of our time. Currently there are an estimated 37 million persons infected with HIV worldwide with more than 35 million AIDS-related deaths to date (1). The development of combination anti-retroviral therapy (ART) has mitigated the severity of this disease, significantly improving survival rates and life expectancy for persons infected with HIV.

Despite these encouraging developments, the number of new HIV infections has remained largely static and co-morbidities including cancers continue to develop in HIV treated individuals. Furthermore, individuals must remain on life-long therapy due to the persistence of latently-infected $\mathrm{CD} 4^{+} \mathrm{T}$ cells, intractable to ART and immune detection due to proviral integration into the host chromosome and being transcriptionally silent, and due to sequestration in anatomical sites largely devoid of HIV specific $\mathrm{CD}^{+} \mathrm{T}$ cells [reviewed in (2)]. In particular, secondary lymphoid sites, such as the gut-associated lymphoid tissue (GALT) and lymph nodes (LN), bear the largest fraction of the HIV burden in ART suppressed individuals (3). Unique microenvironments and distinct compartmentalization of immune subsets within these anatomical sites provide an ideal niche for ongoing viral persistence and limited immune pressure. Although $\mathrm{T}$ cell exhaustion and immune escape further hinder the impact of adaptive HIV-specific $\mathrm{CD}^{+} \mathrm{T}$ cell responses, there are clear examples of persons who spontaneously control HIV for decades without medications (4), indicating that effective HIV immune containment, if not eradication, can be achieved despite these barriers.

As the HIV field has attempted and largely failed thus far to mobilize the immune system to better prevent, treat, and cure infection, the cancer field has experienced dramatic advances through application of immunotherapeutic interventions that either genetically modify and re-direct $\mathrm{T}$ cells or liberate endogenous $\mathrm{T}$ cell responses to tumor neoantigens. Remarkable examples of immune-mediated disease-free remissions have been achieved for some previously intractable malignancies, such as melanoma (5-7), non-small cell lung cancer $(8,9)$, and chemotherapy-refractory leukemia and lymphoma (10, 11). Indeed, key barriers to cancer eradication bear multiple similarities to hurdles experienced in immune control of HIV, such as lack of accessible antigens, chronic immune dysfunction, and tissue microenvironments that impede effective clearance of cancerous cells. The dramatic advances in therapeutic interventions to augment effective $\mathrm{CD} 8^{+} \mathrm{T}$ cell immunity in cancer provide important insights for therapeutic interventions in HIV infection. Here, we discuss the role of $\mathrm{CD}^{+} \mathrm{T}$ cell mediated immunity in HIV and cancer, and lessons learned from the advances in cancer treatment that may aid in the development of HIV cure strategies.

\section{EVIDENCE FOR CTL-MEDIATED CONTROL OF HIV AND CANCER}

Among the most striking data implicating $\mathrm{CD}^{+}$CTLs in control of AIDS virus infections come from rapid rebound of viremia following $\mathrm{CD}^{+} \mathrm{T}$ cell depletion in the non-human primate (NHP) model of SIV infection (12). These data are supported by human data demonstrating rapid emergence of HIV specific $\mathrm{CD}^{+} \mathrm{T}$ cells mediating strong selection pressure concomitant with post peak viral decline (13-15) the observed inverse relationship of HIV-specific CTLs with both viral setpoint and rate of $\mathrm{CD}^{+} \mathrm{T}$ cell loss $(16,17)$ and the profound viral control exhibited by a select group of elite controllers who, in the absence of ART, maintain potent HIV-specific T cell responses and do not progress immunologically [reviewed in (4)]. These untreated elite controllers represent $<1 \%$ of HIV-infected persons, some of whom have been infected for more that three decades and maintain prolonged control of plasma viremia (HIV RNA $<50$ copies/mL of plasma) $(18,19)$.

The role of $\mathrm{CD}^{+} \mathrm{T}$ cells in this remarkable control of HIV is consistently seen in the context of expression of certain "protective" HLA class I alleles such as $B^{*} 27$ and $B^{*} 57$, and specific amino acids lining the class I peptide binding groove that present viral peptides for $\mathrm{CD} 8^{+} \mathrm{T}$ cell recognition $(20,21)$. Containment of viremia in elite controllers has been linked to more polyfunctional $\mathrm{CD} 8^{+} \mathrm{T}$ cells than in persons with progressive disease (22), perhaps in part due to maintenance of virus-specific $\mathrm{CD} 4^{+} \mathrm{T}$ cells (23), as well as enhanced recognition of epitope variants (24).

Complementary evidence of $\mathrm{CD} 8^{+} \mathrm{T}$ cell mediated immune control of HIV also derives from studies of the virus itself. Transmission of amino acid "escape" mutations within the 8-10 amino acid epitopes targeted by CTL is associated with worse outcomes due to replication of pre-adapted viruses $(25,26)$. Other studies have shown impaired viral fitness due to viral mutations associated with $\mathrm{CD} 8^{+} \mathrm{T}$ cell selection pressure (27, 28). More recent studies indicate that persons who spontaneously control HIV without the need for medication do so at least in part by targeting epitopes containing highly networked amino acids that are critical to structure and function of the virus $(29,30)$. These sites are highly mutationally intolerant, such that immune driven mutations are likely to impair viral fitness and be less resolvable by compensatory mutations at secondary sites. In addition, HIV infection and depletion of $\mathrm{CD} 4^{+} \mathrm{T}$ cells, with preferential infection of HIV-specific $\mathrm{CD} 4^{+} \mathrm{T}$ cells (31), exacerbates immune impairment by providing insufficient help for HIV-specific $\mathrm{CD}^{+}{ }^{+} \mathrm{T}$ cells. Indeed, immediate treatment of acute infection leads to preservation of $\mathrm{CD} 4^{+} \mathrm{T}$ cell responses and induction of $\mathrm{CD} 8^{+} \mathrm{T}$ cells with greater functionality (32).

Despite a long history of debate as to whether the immune system plays a role in controlling cancers, particularly of nonviral origin, it is now clear $\mathrm{CD} 8^{+} \mathrm{T}$ cell-mediated immunity is also a major host defense against tumors. In 1909, it was first hypothesized that immune surveillance suppressed the outgrowth of cancers (33), but it took decades to identify cancer neoantigens, giving credence to the idea that tumors could be recognized as foreign (34). Early, in vitro studies demonstrated that melanoma-specific $\mathrm{CD} 8^{+} \mathrm{T}$ cells could lyse tumor targets (35). Further evidence included the identification of tumor associated antigen (TAA) expressed on tumor cells but not on normal cells, and the observation that a high frequency of TAA-specific $\mathrm{CD}^{+} \mathrm{T}$ cells localized within tumors that spontaneously regressed (36). Density of tumor infiltrating 
$\mathrm{CD}^{+} \mathrm{T}$ cells (TILs) has been shown to negatively correlate with progression of colorectal metastasis (37) and oligoclonal expansions of tumor-infiltrating $\mathrm{T}$ cells have been associated with tumor regression (38). Furthermore, the development of checkpoint inhibitors that target and effectively block the PD-1 and CTLA-4 axes have convincingly underscored the importance of endogenous $\mathrm{CD}^{+} \mathrm{T}$ cells in the recognition and elimination of tumor cells, but most importantly that the cancerspecific immune response can be manipulated for therapeutic benefit. Of note, this checkpoint blockade-mediated liberation of anti-tumor $\mathrm{T}$ cell responses is most effective in tumors that have a high mutational burden $(39,40)$ [i.e., that result in greater presentation of neo-antigens, especially those with mismatch-repair defects $(41,42)]$, and in those that upregulate the checkpoint ligands such as PD-L1 $(43,44)$. In addition, engineered autologous $\mathrm{T}$ cells transduced to express synthetic, chimeric antigen receptors, or CAR T cells, have demonstrated that $\mathrm{T}$ cells can be engineered to recognize surface antigens present on tumor cells and successfully eliminate the cancer, particularly lymphoid malignancies like B-cell leukemia (45), lymphoma $(46,47)$, and multiple myeloma (48).

\section{MECHANISMS OF CD8 ${ }^{+}$T CELL IMMUNE FAILURE IN HIV AND CANCER}

Immune failure is a hallmark of cancer and persistent viral infections such as lymphocytic choriomeningitis infection (LCMV), simian immunodeficiency virus (SIV) and HIV. Understanding the mechanisms driving immune dysfunction is critical to the rational development of immunotherapies for the treatment of both HIV and cancer. There are three areas that are particularly relevant to both HIV and cancer, namely immune exhaustion, immune escape, and immunoregulatory factors in the lymphoid tissue (HIV) and tumor microenvironment (cancer).

\section{Immune Exhaustion}

One of the major obstacles to immune control of both HIV and cancers is progressive $\mathrm{T}$ cell exhaustion in the face of ongoing pathogen burden. The original demonstration of this phenomenon came from the lymphocytic choriomeningitis virus (LCMV) model (49). Armstrong and Clone 13 LCMV variants result in vastly different immunological outcomes, associated with differences in antigen load and persistence (50). Clone 13 has two nucleotides that differ from LCMV Armstrong, resulting in ineffective clearance by $\mathrm{CD}^{+} \mathrm{T}$ cells, chronic viremia, and progressive dysfunction of LCMV-specific $\mathrm{CD}^{+}$ $\mathrm{T}$ cells. This includes impaired proliferative capacity and decreased polyfunctionality. Gene expression analysis of virusspecific $\mathrm{CD}^{+} \mathrm{T}$ cells revealed upregulation of the negative immunoregulatory molecule PD-1 on these cells in the context of Clone 13 infection compared to Armstrong (49), indicative of immune dysfunction with ongoing antigen persistence. Importantly, the immune exhaustion was shown to be reversible through blockade of the interaction of PD-1 with its ligand PD-L1 or PD-L2.
These features of $\mathrm{T}$ cell exhaustion are strikingly similar to what is observed in untreated HIV infection and cancer. Chronic viral infection and cancer are both disease states with inadequate antigen clearance. Memory $\mathrm{T}$ cell $\left(\mathrm{T}_{\mathrm{mem}}\right)$ development is impaired, and effector $\mathrm{T}$ cell $\left(\mathrm{T}_{\text {eff }}\right)$ become functionally exhausted with elevated and sustained expression of the check-point receptors like PD-1. The first evidence that reversible $\mathrm{T}$ cell exhaustion occurs in humans came from studies of HIV infected persons, and like in the LCMV model, blockade of the interaction with PD-L1 or PD-L2 could at least partially reverse cellular dysfunction (51). In cancer, in vitro studies showed that tumor-specific T cells in human melanoma metastases share many features of the exhaustion signature that was characterized in LCMV infection (52). Exhaustion was found to be associated with altered epigenetic and transcriptional profiles, a distinct metabolic signature (53-55) and impaired responses to homeostatic cytokines (56). In HIV infection, PD1 levels are significantly increased on $\mathrm{CD}^{+} \mathrm{T}$ cells during chronic HIV infection, directly correlating with plasma viremia and inversely with $\mathrm{CD} 4^{+} \mathrm{T}$ cell counts $(51,57)$. It was also found that $\mathrm{T}$ cells residing within the $\mathrm{LN}$ compartment exhibited even greater levels of inhibitory receptors when compared to the peripheral blood (57) demonstrating anatomical differences in parameters of immune exhaustion, posing the question of how distinct microenvironments shape $\mathrm{T}$ cell function. Indeed upregulation of these immunoregulatory ligands on tumor cells is an important mechanism of immune dysregulation (57). Beyond inhibitory receptor expression, the transcriptional and epigenetic profiling of virus-specific and tumor-specific CD8 T cells has revealed key similarities and differences between $\mathrm{CD}^{+} \mathrm{T}$ cell responses in the two disease settings. Multiple transcriptional regulators have been associated with $\mathrm{CD}^{+} \mathrm{T}$ cell exhaustion, including NFAT, Eomes, BLIMP-1, BATF, FOXO1, FOXP3, IRF4, VHL, c-Maf, implicating various metabolic, and signaling pathways as important contributors to various states of CTL exhaustion [(58-62); reviewed in (50)].

Another consideration in loss of $\mathrm{T}$ cell effector functions in HIV and cancer is depletion or diminished activity of antigenspecific $\mathrm{CD}^{+}{ }^{+} \mathrm{T}$ cells [reviewed in $\left.(63,64)\right]$. These cells enhance CTL expansion, activity, migration, tissue invasion, and memory differentiation. HIV preferentially infects HIV-specific $\mathrm{CD} 4^{+} \mathrm{T}$ cells (31), and loss of these cells is associated with a reversible defect in $\mathrm{CD}^{+} \mathrm{T}$ cell in vitro proliferation (65). CD27 agonism was shown to recapitulate $\mathrm{CD} 4^{+} \mathrm{T}$ cell help by improving induction of effector $\mathrm{CD}^{+} \mathrm{T}$ cells, antigen-specific cell killing, and overall survival in a murine cancer vaccine model (63). Loss of $\mathrm{CD}^{+}{ }^{+} \mathrm{T}$ cells by HIV infection, or diminished antigen-specific $\mathrm{CD}^{+}{ }^{+} \mathrm{T}$ cell activity by tumor or virus-induced downregulation of MHC class II impairs induction, expansion, and efficacy of CTL responses capable of viral or tumor clearance, and means to rectify this are needed for both HIV and cancer.

\section{Immune Escape}

Effective primary $\mathrm{CD}^{+} \mathrm{T}$ cell responses may drive viral or tumoral evolution, particularly in the context of rapidly mutating pathogens, allowing the outgrowth of variants that are no longer recognized by the host $\mathrm{CD} 8^{+} \mathrm{T}$ cell response. This has been 
termed $\mathrm{CD} 8^{+} \mathrm{T}$ cell escape in the HIV context [reviewed in (66)], and tumor immunoediting in the cancer field [reviewed in (67)], rendering initial $\mathrm{CD}^{+} \mathrm{T}$ cell responses ineffective. Following immune escape, induction of effective de novo $\mathrm{CD}^{+} \mathrm{T}$ cell responses targeting the mutated epitope or a different epitope is necessary to restore antigen-specific immune control.

In HIV infection, where more than 300 viral epitopes and their restricting class I alleles have been defined, immune escape occurs during the initial period of peak viremia [reviewed in (68)]; moreover, transmission of $\mathrm{CD} 8^{+} \mathrm{T}$ cell immune escape variants is already shaping global viral evolution (69). Of particular relevance to any immunotherapeutic approaches is the finding that the majority of immunodominant CTL epitopes in persons with chronic infection may harbor escape mutations (70), such that simple reversal of CTL dysfunction may be insufficient to augment an antiviral effect.

$\mathrm{T}$ cell responses against tumor-associated antigens (TAAs) may be rendered ineffective by immune escape in tumors with high mutation burden. The concept of tumor immunoediting encompasses three phases of the interaction between the protective aspects of adaptive immunity against cancers as well as the "tumor sculpting" functions of the immune response: elimination, equilibrium, and escape (71). TAAs arise from non-synonymous somatic mutations (NSSMs) in proteincoding genes, aberrant expression of an embryonic, placental, testes or other tissue-specific differentiation genes, aberrant overexpression of a wild type gene, and viral proteins expressed by cancer cells. In contrast, the high mutability of HIV is due to the infidelity of the viral reverse transcriptase, which induces errors during the process of converting incoming viral RNA into proviral DNA. On the positive side, mutations that escape adaptive immune surveillance may also inflict a fitness cost to the virus or cancer cell and thus serve to the advantage of the host. And in the HIV context, predictable mutations that arise under immune selection pressure can be incorporated into vaccine immunogens, such as is currently being tested in an efficacy trial of a mosaic vaccine (72).

\section{Tumor and Lymph Node Microenvironments}

One of the shared challenges for $\mathrm{CD}^{+} \mathrm{T}$ cell mediated clearance of HIV or cancer is the need for migration into and induction of effector function within immunosuppressive tissue environments. In HIV infection, this involves the lymph node microenvironment (LNME), whereas in cancer the tumor microenvironment (TME) is the major site of immune engagement (Figure 1).

Lymph nodes (LN) are not only the inductive site for adaptive immune responses, but are a major site of HIV infection [reviewed in $(79,80)$ ]. They are characterized by interaction of lymphocytes and antigen-bearing dendritic cells (DC) within a fibroblastic reticular network (FRC) (81). Localization of DC subsets, stromal cells, and immune cells within the LN in combination with various cytokines, costimulatory signals, secondary metabolites and the amount and nature of foreign antigen (82-84) impact $\mathrm{T}$ cell differentiation by establishing distinct microenvironmental niches (85). Moreover, the LNME is largely immunosuppressive, regulating both naïve and preactivated $\mathrm{T}$ cells through the production of indolamine 2-3 dioxygenase (IDO), Prostaglandin E2 $\left(\mathrm{PGE}_{2}\right)$, adenosine $2 \mathrm{~A}$ receptor (A2AR) agonists and tumor growth factor $\beta$ (TGF $\beta$ ) $(78,86)$.

As the major site of HIV replication is in $\mathrm{CD} 4^{+} \mathrm{T}$ cells, LNs and the gut associated lymphoid tissue are the initial and persistent targets of infection. Importantly, germinal centers (GC) within LN are important anatomic sites for HIV persistence [reviewed in (87)]. Peripheral blood $\mathrm{CD}^{+}{ }^{-} \mathrm{T}$ cells constitute $\sim 0.2 \%$ of the HIV reservoir, whereas lymphoid resident $\mathrm{CD} 4^{+}$ $\mathrm{T}$ cells represent $>50 \%$ of the overall HIV burden (3). T follicular helper cells (Tfh, defined as CXCR5 ${ }^{\text {hi }} \mathrm{PD}-1^{\text {hi }} \mathrm{CD} 4^{+} \mathrm{T}$ cells) accumulate during chronic HIV/SIV infection, and are highly susceptible to HIV infection (88-91), contributing to both viral production and persistence during chronic untreated and treated HIV infection. Importantly, germinal centers largely exclude HIV-specific CTLs (92).

Progressive dismantling of the FRC networks within lymphoid tissue during HIV infection (93), a consequence of profound $\mathrm{CD} 4^{+} \mathrm{T}$ cell loss, results in increased collagen deposition and significant fibrosis (93-95). These alterations restrict access to IL-7 and limit the life-span of naïve $\mathrm{CD} 4^{+}$and $\mathrm{CD} 8^{+} \mathrm{T}$ cells within the $\mathrm{LN}$ and the overall generation of $\mathrm{T}$ cell immunity within the lymphoid tissue. Excessive accumulation of collagen and other extracellular matrix (ECM) components that occur during HIV/SIV infection has been linked to an early induction of an immunoregulatory response within secondary LT such as increased levels of TGF $\beta$ (96-98).

In contrast to the limited understanding of the LNME during chronic HIV/SIV, the TME and its corresponding impact on immune function has been well-characterized. The physical and chemical content within the TME such as the extracellular matrix (ECM), fibroblasts, stromal cells, myeloid cells, and immune cells as well as secreted chemokines and cytokines, collectively impact tumor progression and impair immune function either directly or in trans (99). The induction and localization of immune subsets such as regulatory $\mathrm{T}$ cells (Tregs), myeloid-derived suppressor cells (MDSCs), tumor infiltrating DCs (TIDCs), and tumor-associated macrophages (TAMs) can hinder effector function and $\mathrm{CD}^{+} \mathrm{T}$ cell infiltration and actively contribute to the maintenance of $\mathrm{CD}^{+} \mathrm{T}$ cell exhaustion. Tumor cell oncogenic pathways, including oncogenic $\mathrm{Wnt} / \mathrm{B}$-Catenin signaling and gain of function MYC have also been shown to impart immunosuppressive signals within the TME that limit $\mathrm{T}$ cell recruitment, activation, and infiltration [reviewed in (100)]. Transcriptional regulation through Signal Transducer and Activator of Transcription 3 (STAT3) within $\mathrm{CD}^{+} \mathrm{T}$ cells has also been implicated in limiting $\mathrm{CD} 8^{+}$ $\mathrm{T}$ cell recruitment to (101) and cytotoxic function within (102) tumors. Significant metabolic challenges also occur within the TME which impact $\mathrm{T}$ cell function and tumor regression including hypoxia, decreased $\mathrm{pH}$, increased levels of extracellular adenosine, high interstitial fluid pressure, and increased extracellular matrix (ECM) stiffness, akin to what is observed during LN fibrosis in chronic HIV infection. 


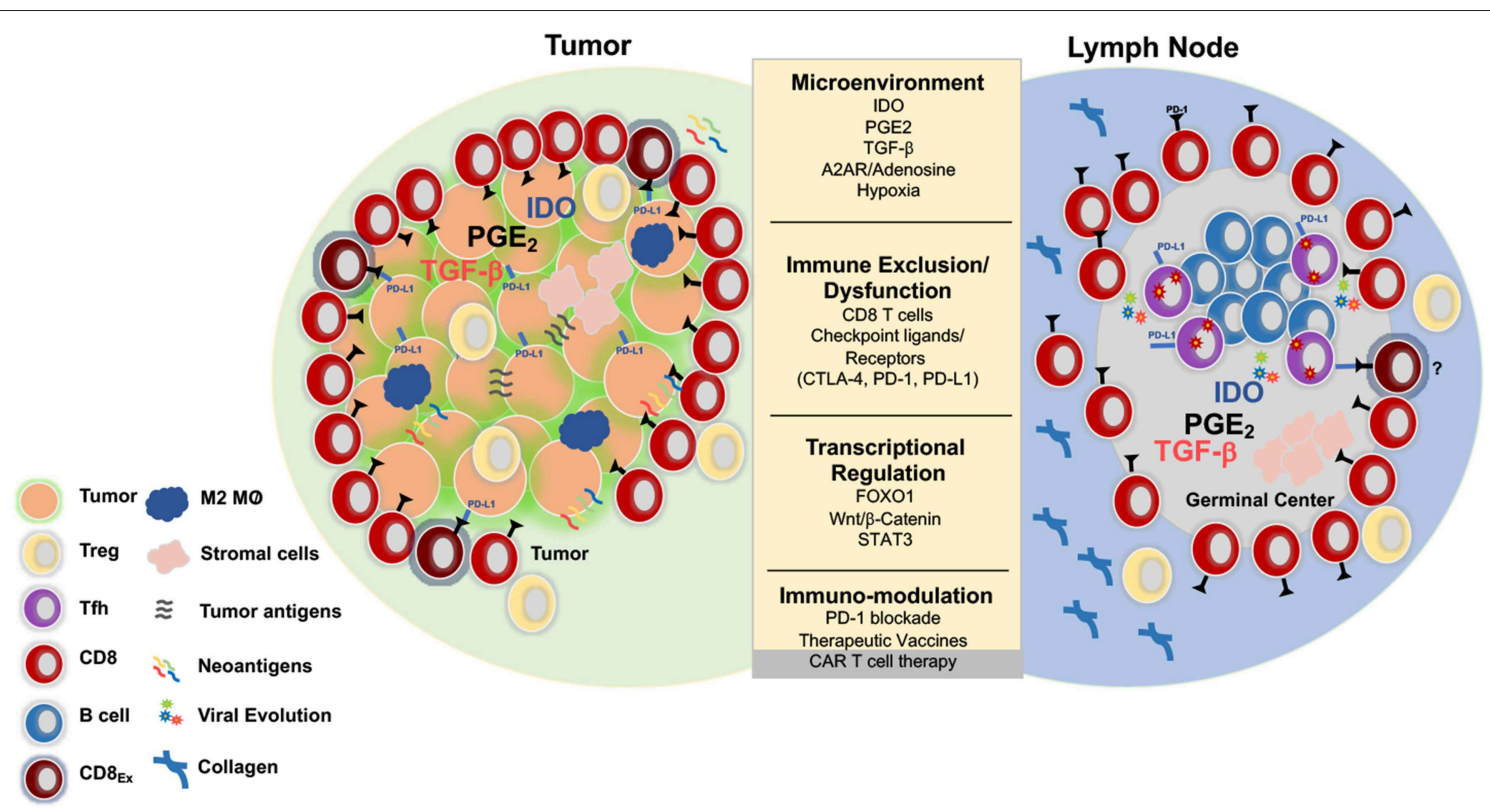

FIGURE 1 | Parallels between immunoregulation in solid tumors and lymph nodes. Tumors and LNs are composed of stromal and immune cells that secrete cytokines and growth factors such as transforming growth factor b (TGFB), prostaglandin E2 (PGE2), indolamine 2-3-dioxygenase (IDO), and adenosine that shape the tumor and LN microenvironment and collectively contribute to suppression of the T cell response. Adenosine signals through the adenosine 2A receptor (A2AR) and promotes production of cyclic AMP, which impairs T cell trafficking, proliferation, and cytotoxicity (73). Immunosuppression is also induced by regulatory T cells (Treg) that express higher levels of CTLA-4, an inhibitory receptor that outcompetes CD80/CD86 on the surface of effector cells and promotes the production of IDO, an enzyme that degrades tryptophan and leads to impaired proliferation and Treg differentiation. Additionally, Tregs express high levels of CD73/CD39, enzymes that convert ATP to adenosine, which inhibit immune function $(74,75)$. Tumors upregulate inhibitory ligands such as PD-L1 that bind to inhibitory receptors resulting in suppression of adaptive immune responses (75). Several strategies have been developed in the immune-oncology field to overcome these barriers such as checkpoint blockade, small molecule inhibitors, therapeutic vaccines, and CAR T cell therapy. These immune based therapies can all be extended to the HIV cure field. Several mechanisms that result in resistance to checkpoint blockade and CD8T cell exclusion include activation of the WNT/ $\beta$-catenin pathway (76), localization of M2 macrophages within the tumor (77), and the secretion of TGF $\beta$ (78).

Tumor associated hypoxia commonly occurs during the later stages of cancer, but hypoxia inducible factors (HIFs) can be upregulated due to acidification and glycolytic metabolites within the TME. The concerted effort to understand the TME has led to the development of immune based therapies, currently in clinical trials for the treatment of solid tumors [reviewed in (103)].

Limitations to $\mathrm{CD} 8^{+} \mathrm{T}$ cell trafficking act to impede immune clearance in both HIV infection and solid tumors. Through a variety of mechanisms, $\mathrm{CD}^{+} \mathrm{T}$ cells appear to be excluded from both solid tumor masses and LN germinal centers. In both HIV and numerous tumors the relative frequency of tumor infiltrating or GC infiltrating $\mathrm{CD}^{+} \mathrm{T}$ cells is inversely correlated with disease outcome in numerous cancers and HIV infection, respectively (104-108). Studies have demonstrated that intra-follicular localization of $\mathrm{HIV}$ specific $\mathrm{CD}^{+} \mathrm{T}$ cells is correlated with lower plasma viremia (106); however, whether the cytolytic function of these $\mathrm{CD} 8^{+} \mathrm{T}$ cells mediates control remains unknown. Studies from patients with follicular lymphomas (FL, tumors situated in LN) indicate that the presence of functional granzyme $\mathrm{B}^{+}$CTLs at the follicular border within the LN correlated with prolonged progression free-survival (109), whereas higher levels of the inhibitory receptor TIM3 on FL CTLs correlated with shorter relapse-free survival (110).

Understanding the immune suppressive elements of the LNME and TME are likely to lead to additional avenues to immunotherapy. For example, one potential mechanism of immunoregulation shared between the LNME and TME is the pleiotropic cytokine TGF $\beta$. TGF $\beta$ has been shown to promote immune exclusion, impair immune function, and limit responsiveness to check-point blockade in metastatic urothelial cancer and other tumors $(78,111)$. Administration of a TGF $\beta$ blocking antibody in combination with anti-PD-L1 has been shown to promote $\mathrm{T}$ cell localization within tumors and enhance anti-tumor immunity, leading to increased regression $(78,112)$. Higher levels of TGF $\beta$ have also been observed in the LN during progressive HIV infection. These shared observations suggest that immunoregulation via TGF $\beta$ might be playing a similar role in restraining $\mathrm{CD}^{+} \mathrm{T}$ cell effector function in the LNME and TME. These data demonstrate the potential for $\mathrm{CD}^{+} \mathrm{T}$ cells within LN sites to exhibit cytotoxicity. However, further investigation is required to elucidate the conditions under which $\mathrm{CD}^{+} \mathrm{T}$ cell cytotoxicity can occur within the $\mathrm{LN}$, which will have direct implications for the development of HIV cure therapeutics. 


\section{IMPLICATIONS FOR IMMUNOTHERAPEUTIC INTERVENTIONS}

Therapeutic vaccines and immune based therapies aimed at achieving durable remission or cure of HIV have garnered significant interest within the HIV cure field with the identification of the first functionally cured individual known as the "Berlin patient" $(113,114)$ and hopeful second case reported in London earlier this year (115). Both underwent allogeneic hematopoietic stem cell transplant (HSCT) from HIV-resistant CCR5 $\triangle 32$ homozygous donors, resulting in reduced expression of the CCR5 co-receptor required for HIV entry. Both patients exhibited virological and immunological features of remission and have been considered cured. However, there is limited feasibility in applying HSCT as a standard of care approach to curing HIV due to toxicity, cost, availability of CCR $5 \Delta 32$ HSCs and continued susceptibility to infection with CXCR4-utilizing strains $(116,117)$. The profound outcomes observed in these two cases have nevertheless energized efforts to develop safe and effective HIV cure strategies. Since robust immunological remissions occur in the 1 in $300 \mathrm{HIV}$ infected persons (elite controllers), immune based approaches toward a functional cure are in our view the most rational approach. Given that immunotherapeutic interventions have transformed the cancer field, review of those therapeutic successes is likely to provide critical information for advancing HIV immunotherapy efforts.

\section{Biological Inhibition of Immuno-Regulatory Pathways}

Immune check-point inhibitor (ICI) therapy targeting the CTLA4 and PD-1 pathways has profoundly altered the management of several cancers, significantly enhancing anti-tumor responses and prolonging progression-free survival. CTLA-4 competes with the co-stimulatory molecule CD28 for binding to CD80/86 on antigen presenting cells, resulting in attenuation of $\mathrm{T}$ cell signaling. Ipilimumab, a monoclonal antibody to CTLA-4, blocks this interaction and prevents the inhibitory signal, allowing CTL to kill cancerous or virus infected cells. Pembrolizumab and nivolumab, monoclonal antibodies targeting the PD-1 pathway, engage the PD-1 ligand on target cells, resulting in dephosphorylation of TCR proximal signaling and decreased polyfunctionality, cell cycle progression, survival, and effector function $(118,119)$. Ipilimumab was the first FDA approved ICI, based on studies in advanced melanoma showing a modest improvement in the overall survival of patients previously treated for metastatic melanoma (120). At present, overall response rate of single ICI therapy is only about $30 \%$ in most tumor types for which activity has been shown, such as non-small cell lung cancer (NSCLC), renal cell carcinoma, and metastatic melanoma (7, 121, 122). Biomarkers of ICI responsiveness include an immune inflamed tumor phenotype, described as a gene signature of immune related genes (123), pre-existing anti-tumor $\mathrm{CD}^{+} \mathrm{T}$ cells (124), low levels of circulating immunoregulatory cells and cytokines such as IL-10 and TGF $\beta$ (125), and a high tumor mutational burden which leads to high levels of tumor associated neoantigens, presumably associated with neoantigen-specific $\mathrm{T}$ cells $(126,127)$.

Efforts to better predict treatment outcomes are advancing effective implementation of ICI therapy for cancer. Parameters including displayed increased localization of $\mathrm{CD}^{+} \mathrm{T}$ cells to the tumor core, and increased expression of check-point regulators such as PD-L1 expression on tumor stroma have been shown to correlate with positive disease response to ICI $(126,128)$. Interestingly, these findings parallel the association of follicular infiltrating $\mathrm{CD}^{+} \mathrm{T}$ cells within germinal centers during HIV/SIV infection. Higher frequencies within the GC are associated with reduced plasma viral loads during chronic infection, and these cells retain higher levels of inhibitory receptors $(105,106,108,129)$ and are more responsive to antiPD-1 therapy (130).

Despite the fact that the initial demonstration of ICI leading to augmentation of CTL function came from studies of HIV, the effective use of ICI in HIV infected individuals is yet to be realized. Indeed, most in vivo data assessing ICI for the treatment of AIDS virus infection have been generated in the SIV macaque model. In vivo PD-1 blockade of progressive SIV infection resulted in an increase in magnitude and quality of SIV specific $\mathrm{CD}^{+} \mathrm{T}$ cells $(131,132)$, anti-viral B cells $(131)$ and a transient decline in plasma viremia - a clear signal but far short of the best outcomes in cancer. A separate study observed a decrease in hyperimmune activation and microbial translocation in macaques treated with anti-PD-1 (133). Several limited case reports demonstrated that PD-1 blockade promoted increased anti-viral immunity in HIV infected patients and was tolerated $(134,135)$, but toxicity concerns remain.

$\mathrm{PD}-1$ expression on $\mathrm{CD}^{+} \mathrm{T}$ cells has also been explored as a potential cellular biomarker of immune cells enriched in active and latent SIV/HIV (89-91, 136-138). In vitro studies have described variable effects of PD-1 blockade on disrupting the latent viral reservoir (139), and substantial reactivation of the latent HIV reservoir with anti-PD-1 alone (140) and in combination with the latency reversal agent (LRA) bryostatin (141). In a macaque study, anti-PD-1 administration during suppressive ART led to transient increase in plasma viremia and a reduction in replication competent virus (142). These data suggest that PD-1 signaling may play a role in maintaining viral latency and blockade may allow for disruption and reactivation of the latent viral reservoir. CTLA- $4^{+} \mathrm{PD}-1^{-} \mathrm{CD} 4^{+} \mathrm{T}$ cells have also been implicated as a subset of $\mathrm{T}$ cells enriched in viral DNA during suppressive ART (143). A recent open-label study found that ascending doses of anti-CTLA-4 were well-tolerated and showed variable changes in detectable plasma viral RNA (144). Check-point blockade monotherapies have elicited modest immunological responses and reactivation of the viral reservoir, suggesting that combination therapeutic approaches may be required for significant destabilization of the HIV reservoir.

We believe that check-point blockade should be considered cautiously as a treatment modality for HIV, as ICIs carry significant toxicity profiles, setting a higher bar when alternative HIV treatments are available. Following ICI therapy for cancer, immune-related adverse events (irAEs), and increased immune cell infiltration into healthy tissues have caused autoimmune-like 
toxicities. Severe irAEs are more common with ipilimumab (15$43 \%$ of patients) than nivolumab or pembrolizumab. However, $10-23 \%$ of patients given anti-PD-1 therapy still develop potentially life-threatening toxicities, that increase with coadministration of anti-CTLA-4 (145). A comprehensive metaanalysis conducted to assess irAE's resulting from ICI found higher risk of all-grade rash and colitis with anti-CTLA-4 treatment (146) and a case study of a patient with widespread uveal melanoma had an exceptional response to ipilimumab and nivolumab but suffered severe immune-related sequelae, with identical T cell clones found in the tissues affected (147). Moreover, a recent report assessing patients treated with a singleagent nivolumab or pembrolizumab for advanced cancer found an overall response rate of $82.5 \%$ in patients experiencing irAE (148), highlighting autoimmunity as an emerging biomarker for responsiveness to ICI. Thus, there is an ongoing medical need to not only define biomarkers of ICI resistance, but identify mechanisms underlying cross-reactivity and toxicity as well, in an effort to develop therapies that promote remission while limiting immune toxicities.

\section{Adoptive T Cell Therapy}

Chimeric antigen receptor (CAR) $\mathrm{T}$ cell immunotherapy has emerged as an important adoptive $\mathrm{T}$ cell therapy for the treatment of cancer with the recent FDA approval of the CD19targeted CAR T cell "living drug," tisagenlecleucel (Kymriah) for the treatment of adult and pediatric B cell malignancies (45). CARs are synthetic receptors comprised of a singlechain variable fragment ( $\mathrm{scFV}$ ) of an antibody fused to a transmembrane domain and intra-cellular signaling complex [reviewed in (149)]. CAR T cells can re-direct specificity, functionality, and localization of $\mathrm{T}$ cells. Clinical trials have shown dramatic outcomes in patients with relapsed, refractory B cell cancers. A phase II clinical trial utilizing the CD19targeting CAR for the treatment of B cell acute lymphoblastic leukemia (ALL) observed an $81 \%$ complete response (CR) rate at 28 days of follow-up, and a relapse-free survival of 59\% with a short median 12-month follow-up. Despite initial high rates of remission, a significant fraction of patients will relapse with $\mathrm{CD}_{19}{ }^{+}$or $\mathrm{CD} 19^{-}$tumors due to decreased persistence/function of the CAR T cells, antigen loss, and impairment due to the immunosuppressive tumor microenvironment (150). Increased persistence of circulating CAR T cells correlated with durable responses and improved clinical outcomes, indicating that these therapies can be further improved (151). This is especially true for CAR T cells that contain the 4-1BB costimulatory domain, which allows the CAR T cells to primarily utilize oxidative metabolism vs. glycolysis which CD28 costimulatory CARs rely on, allowing for enhanced persistence (152).

Despite persistence of CAR T cells, relapses can occur due to antigen loss post CAR infusion, which accounts for $40 \%$ of relapses (153). Moreover, the immunosuppressive tumor microenvironment significantly contributes to poor clinical outcomes by inducing early dysfunction, decreased expansion of CAR T cells, and limited persistence in vivo (154). A new generation of CAR T cells is being constructed to overcome these immune barriers. Alternative strategies include the development of CAR constructs targeting antigens other than CD19, the generation of bi-specific CARs that target more than one antigen, cytokine secreting CARs that produce IL-12 (155) and IL-18 (156), or anti-PD-1 (157). Additionally, CAR T cells may be engineered to express chemokine receptors and cytokines to improve their homing and tumor infiltration, but the efficacy of these approaches has not yet been confirmed in clinical trials. One example of this approach is engineering CAR T cells to express IL-7 and CCL19 (158) to enhance survival and T cell trafficking to secondary lymphoid sites, respectively.

Chimeric antigen receptor (CAR) $\mathrm{T}$ cell therapy for HIV actually predates its use in cancer, with the first studies completed in the mid 1990's, when a CD4-based CAR, shown to be effective in vitro and safe and well-tolerated in vivo, provided no clear clinical benefit and no reduction in the peripheral viral reservoir $(159,160)$. Follow-up studies attributed lack of efficacy to limited CAR $\mathrm{T}$ cell persistence, likely due to the high IL-2 dose used in manufacturing. The CAR contained CD4 extracellular and transmembrane domain, which might have increased CAR T cell susceptibility to infection, but lacked costimulatory domains, which could limit cellular functionality (161). Inclusion of costimulatory domains has been shown to be critical for CAR $\mathrm{T}$ cell efficacy in cancer. Despite limited function, there were no associated malignancies found with the transduced infused HIV CD4 CARs, which was promising for virally transduced adoptive $\mathrm{T}$ cell therapy. In the last several years, a growing number of high affinity broadly neutralizing antibodies (bNAbs) has been identified against HIV passive antibody infusion trials assessing the efficacy of HIV bNAbs have produced modestly decreased viral loads in viremic patients (162), increased clearance of infected cells (163), a delay in viral rebound $(164,165)$ and viral suppression post treatment interruption in $30 \%$ of patients until bNAb titers waned. Moreover, VRC01 and PGT121, bNAbs targeting the CD4 binding site and the V3 glycan of env, respectively, blocked HIV-1 replication from reactivated latently infected cells in vitro (166).

The growing repertoire of HIV bNAbs and enhanced function and persistence of second and third generation CAR $\mathrm{T}$ cell vectors have propelled efforts to design bNAb CARs for HIV remission or cure. Several groups have reported the development of bNAb and CD4 expressing CAR T cells (CD4 CAR) that can effectively limit HIV replication in vitro (159, 167-169). Moreover, the recent identification of follicular CXCR5 ${ }^{+} \mathrm{CD} 8^{+}$ $\mathrm{T}$ cells and their potential contribution to control of viral replication within GC "hotspots" of active and latent HIV, has led to the development of HIV CAR T cells that over-express the chemokine receptor CXCR5, to promote trafficking into $\mathrm{B}$ cell follicles. A proof-of-concept study in macaques showed that infusion of $\mathrm{CD} 8{ }^{+} \mathrm{T}$ cells overexpressing rhesus CXCR5 increased localization within the GC (170). A separate group developed CXCR5+ CAR T cells expressing the CD4 co-receptor for HIV env specificity and found the cells functionally capable of limiting SIV infection in vitro and chemotaxing in response to CXCL13 in transwell and LN organoid cultures (171). These studies highlight the potential feasibility of developing virus-specific CAR T cells with an increased ability to traffic to specific anatomical sites such as GC that harbor a large fraction of the HIV reservoir. 
Several considerations should be taken in developing adoptive cell therapies that enhance $\mathrm{CD}^{+} \mathrm{T}$ cell trafficking to and detection of infected $\mathrm{CD}^{+} \mathrm{T}$ cells in $\mathrm{GC}$ of lymphoid tissue. In contrast to tumor masses, $\mathrm{GC} / \mathrm{B}$ cell follicles are critical anatomical sites for the induction of systemic immunity. Tfh cells localized within GC not only harbor a significant fraction of the HIV reservoir but are key mediators in the development of humoral immunity. Enhanced infiltration of $\mathrm{CD}^{+} \mathrm{T}$ cells into the GC of LN may impact antibody development and pathogen specific immunity. Of note, recent trials assessing the efficacy of re-programmed autologous CAR $\mathrm{T}$ cells for the treatment of follicular lymphoma (FL) demonstrated successful restoration of immune function in patients with relapsed or refractory disease (172); however cytokine release syndrome (CRS) and neurotoxicities were experienced in line with what has been observed in other CAR T cell trials. Additional studies to assess the efficacy of ICI in the context of FL found varying objective response rates with some measured as high as $67 \%$ (172). However, with limited power in these studies, it is unknown whether ICI treatment of FL comes with a similar toxicity profile to what has been observed in other ICI responsive cancers. These findings suggest that enhanced accumulation of CD8+ $\mathrm{T}$ cells within lymphoid sites may be mechanistically supported and immunologically tolerated, but further studies need to be conducted to understand $\mathrm{CD}^{+} \mathrm{T}$ cell targeting of LNME and the associated toxicities of targeting cells at LN sites.

Additionally, although the LNME has not been fully characterized in the context of HIV infection, collective data suggest an immunosuppressive environment may hamper the local functionality of CAR T cells. Immuno-oncology strategies to enhance intra-tumoral CAR $\mathrm{T}$ cell efficacy may serve to overcome similar constraints of the LNME. Strategies include combining CAR $\mathrm{T}$ cells with ICI therapy and development of CAR T cells with endogenous PD-1 knockout or encoding secretable check-point inhibitors and effector cytokines such as IL-18 (156, 173), IL-12 (174), or a tethered IL-15 (175), as well as engineering $\mathrm{T}$ cells to express a domain-negative form of the TGF $\beta$ receptor $(176,177)$. A recent in vivo trial in macaques using the human IL-15 superagonist ALT-803 demonstrated enhanced trafficking of SIV specific $\mathrm{CD}^{+} \mathrm{T}$ cells to B cell follicles. HIV specific CARs with the ability to secrete IL-15 in situ may direct localization of these cells within B cell "sanctuary sites." Additionally, there is potential for viral escape following treatment with HIV-specific CAR T cells that target a single HIV env epitope, similar to what was observed in phase 1 studies assessing single infusions of bNAbs targeting distinct HIV-1 envelope epitopes $(164,178)$. However, more recent studies have found that despite selection of escape variants, rebound viruses did not show further resistance to other antibodies that targeted different envelope epitopes $(164,165,178)$ and combination approaches with multiple bNAb scFVs can maintain viral suppression (179) and limit viral resistant variants. Thus, combination multi-specific CAR $\mathrm{T}$ cell approaches could be taken to promote durable viral control. Further studies need to be conducted to assess the in vivo potential of the single and multi-specific bNAb CAR T cells to reduce the HIV reservoir and mediate post-treatment viral control. What is very clear is that advances in CAR T cell therapy for cancer and HIV will benefit both.

\section{Therapeutic Vaccines}

The rationale for therapeutic vaccines is similar for cancer and for HIV: for both tumors and viruses, genomic heterogeneity limits the efficacy of naturally induced immune responses, and in both diseases, there is compelling evidence revealed by next generation sequencing and advances in bioinformatics to suggest that targeting the $\mathrm{CD}^{+}{ }^{+} \mathrm{T}$ cell response to specific epitopes may be beneficial. Moreover, in both diseases there is evidence for dysfunctional natural immune responses that might be countered by therapeutic immunization. For cancer, there are now multiple vaccines that have been licensed by the FDA, and exciting new advances from early phase human clinical trials targeting cancer neoantigens (180), but for HIV, despite some promising results in monkeys infected with SIV, human studies have mostly been disappointing. This is thus an overlap area that deserves considerable attention.

The first attempt at therapeutic vaccination for cancer came over a century ago with the administration of bacterial toxin directly into tumors, which led to tumor regression in a person with an advanced sarcoma (181). This was the first evidence that a tumor-specific immune response could be augmented by immunization. In the cancer field today, there are multiple licensed therapeutic vaccines, starting in 2010 with FDA approval of Sipuleucel-T (Provenge; Dendreon), an autologous dendritic cell vaccine for prostate cancer (182). Autologous and allogeneic tumor vaccines have been tested in different cancer modalities, enhancing anti-tumor responses and prolonging survival $(183,184)$. GVAX, the most extensively studied whole cell vaccine which is comprised of irradiated, allogeneic, or autologous pancreatic tumor cells genetically engineered to secrete granulocyte colony stimulating factor (GM-CSF), has been used in pre-clinical and clinical studies in an attempt to stimulate dendritic cell activation and $\mathrm{T}$ cell priming (185). Despite an observed increase in anti-tumor immunity (186), a phase II trial with GVAX in combination with cyclophosphamide for the treatment of pancreatic cancer failed to show an increase in overall survival (187). More recent advances have been associated with individualized vaccines using tumor whole exome sequencing to identify autologous neoantigens, which have been shown to be immunogenic for intratumoral $\mathrm{CD}^{+}$and $\mathrm{CD}^{+}{ }^{+} \mathrm{T}$ cell responses in early phase clinical trials in glioblastoma (180). Thus, far the impact on disease course has been modest, and none of these approaches has effected a cure or sustained remission.

In the setting of HIV infection, there have been multiple attempts at therapeutic vaccination to augment HIV-specific $\mathrm{CD}^{+} \mathrm{T}$ cell responses, but thus far there have been no clear successes in humans. Studies of DC based immunotherapy clinical trials conducted for the treatment of HIV have shown modest immunogenicity and modest impact on viral load (188-191), which has often been difficult to interpret due to lack of appropriate controls. More promising results come from recent studies in NHPs suggest that immune modulation 
may be possible. Several studies conducted in rhesus macaque models have underscored the importance of generating a robust anti-viral CTL response for therapeutic SIV/HIV control. An epidermally administered DNA vaccine expressing highly conserved elements (CE) of the SIV capsid protein p27 in SHIV infected macaques experiencing chronic but controlled SHIV infection. Macaques experiencing a stronger induction of CE specific responses exhibited lower plasma viral loads (192). In a separate study, Ad26/MVA (recombinant adenovirus 26 serotype (Ad26) prime/modified vaccinia Ankara (MVA) boost) with a TLR-7 (Toll-like receptor 7) adjuvant demonstrated a delay in viral rebound and a 2 -log reduction in plasma viral loads post treatment interruption (193), where the breadth of the immune response directly correlated with time to rebound and inversely with plasma viral loads. However, a recent randomized controlled trial utilizing a therapeutic vaccine regimen in HIV infected patients who began cART early during the course of infection, showed a limited induction of antiviral $\mathrm{CD}^{+} \mathrm{T}$ cells, no significant effects on the kinetics of viral rebound, and no reduction in the viral reservoir post discontinuation of ART (194). This was despite the addition of human interleukin (IL)-12p35 and p40 proteins via in vivo electroporation to maximize immunogenicity, previously shown in non-human primates to enhance the potency of the HIV DNA based vaccine $(195,196)$. Moreover, the subjects enrolled in this study were within the acute phase of infection with early cART treatment and potentially better preserved immune function, but still failed to show any effect on posttreatment control.

For both HIV and cancer, epitope mutation resulting in immune escape appears to play a major role in the lack of efficacy of host $\mathrm{T}$ cell responses, but recent studies suggest that this property may be exploited to therapeutic benefit. In cancers, neoantigens which can be bioinformatically identified have been used as immunogens and shown promise in early phase human trials $(180,197)$. In HIV infection, application of network theory to HIV structure has revealed that mutation of epitopes at important network positions disproportionately impairs viral replication capacity and that $\mathrm{CD} 8^{+} \mathrm{T}$ cell targeting of highly networked epitopes distinguishes persons who naturally control HIV, even in the absence of protective HLA alleles (30). These data suggest that targeting mutationally constrained epitopes is a promising approach for vaccine design. Support for induction of immune responses to neoantigen epitopes or highly networked epitopes comes from recent studies showing that a synthetic DNA, multi-neoantigen cancer vaccine in a mouse model drives robust $\mathrm{MHC}$ class $\mathrm{I} C D 8^{+} \mathrm{T}$-cell responses which are able to impact tumor growth (198). It is still unknown whether therapeutic vaccinations alone can increase the magnitude of the HIV specific response to a level that can both detect very low antigen levels in ART treated patients as well as induce durable viral suppression upon ART cessation, but future studies incorporating check-point blockade, cell based therapies, and tissue specific/LNME agonists in combination with therapeutic vaccines to develop a functional, highly potent CTL response may be key to containing or eradicating the latent HIV reservoir.

\section{CONCLUSIONS}

HIV remains a significant global health burden and despite the profound efficacy of ART in preventing viral transmission (199), the number of individuals living with HIV and on treatment continues to rise each year and non-AIDS related morbidities are increasing with the duration of HIV and time on ART $(200,201)$. Given the limited impact of ART on viral "sanctuaries," there is a critical need to identify immune mechanisms within tissue sites that harbor the HIV reservoir and hinder anti-viral immunity, similar to the need for immune based therapies in cancer to access malignant cells in tissue sites and overcome tumor immunosuppressive environments. In the same way that advances in cancer immunotherapy have resulted in durable remission in patients with seemingly incurable malignancies, there is strong rationale for immune control if not eradication of HIV, given that some persons are able to achieve a state of immune-mediated functional cure of HIV infection without the need for ART. A deeper understanding of common mechanisms of immune dysfunction and exclusion as well as mechanisms of tumor response leading to durable remission, will be critical to attaining a functional state of viral remission or cure in HIV infected patients. These include enhancing $\mathrm{T}$ cell trafficking into tumors and lymph node HIV sanctuaries, overcoming immune exhaustion, and escape, reversing tumor and lymph node immunosuppressive environments, and eliciting robust CTL responses against neoepitopes and highly networked epitopes. Caution, however, must be taken when exploring immunotherapeutic interventions to avoid emergence of autoimmunity and other adverse events. A greater understanding of the immune mechanisms regulating the LN microenvironment and the impact of check-point blockade on CTL function, localization, and viral clearance within the LNME will be crucial to the development of HIV cure strategies. Thus, as the field of cancer immunotherapy progresses, the HIV cure field must take heed in determining what therapeutic interventions will prove safe, effective, and clinically justifiable to explore in HIV infected individuals currently durably suppressed with ART.

\section{AUTHOR CONTRIBUTIONS}

GM and AY carried out the primary research and equally wrote the manuscript. MM edited the manuscript. BW provided oversight in preparation and editing.

\section{FUNDING}

This work was supported by the USA National Institutes of Health (NIH) grant UM1AI100663. 


\section{REFERENCES}

1. Eisinger RW, Fauci AS. Ending the HIV/AIDS Pandemic (1). Emerg Infect Dis. (2018) 24:413-6. doi: 10.3201/eid2403.1 71797

2. Siliciano JD, Siliciano RF. Recent developments in the effort to cure HIV infection: going beyond $N=1$. J Clin Invest. (2016) 126:40914. doi: $10.1172 /$ JCI86047

3. Buggert M, Japp AS, Betts MR. Everything in its right place: resident memory CD8+ T cell immunosurveillance of HIV infection. Curr Opin HIV AIDS. (2019) 14:93-9. doi: 10.1097/COH.00000000000 00523

4. Walker BD, Yu XG. Unravelling the mechanisms of durable control of HIV-1. Nat Rev Immunol. (2013) 13:487-98. doi: 10.1038/nri3478

5. Wolchok JD, Kluger H, Callahan MK, Postow MA, Rizvi NA, Lesokhin AM, et al. Nivolumab plus ipilimumab in advanced melanoma. $N$ Engl J Med. (2013) 369:122-33. doi: 10.1056/NEJMoa1302369

6. Hamid O, Robert C, Daud A, Hodi FS, Hwu WJ, Kefford R, et al. Safety and tumor responses with lambrolizumab (anti-PD-1) in melanoma. $N$ Engl $J$ Med. (2013) 369:134-44. doi: 10.1056/NEJMoa1305133

7. Topalian SL, Hodi FS, Brahmer JR, Gettinger SN, Smith DC, McDermott DF, et al. Safety, activity, and immune correlates of anti-PD-1 antibody in cancer. N Engl J Med. (2012) 366:2443-54. doi: 10.1056/NEJMoa1200690

8. Forde PM, Chaft JE, Pardoll DM. Neoadjuvant PD-1 blockade in resectable lung cancer. N Engl J Med. (2018) 379:e14. doi: 10.1056/NEJMc1808251

9. Garon EB, Rizvi NA, Hui R, Leighl N, Balmanoukian AS, Eder JP, et al. Investigators: pembrolizumab for the treatment of non-small-cell lung cancer. N Engl J Med. (2015) 372:2018-28. doi: 10.1056/NEJMoa1501824

10. Kataoka K, Ogawa S. PD-1 inhibitor therapy in adult T-cell leukemialymphoma. N Engl J Med. (2018) 379:696. doi: 10.1056/NEJMc1807852

11. Ansell SM, Lesokhin AM, Borrello I, Halwani A, Scott EC, Gutierrez M, et al. PD-1 blockade with nivolumab in relapsed or refractory Hodgkin's lymphoma. N Engl J Med. (2015) 372:311-9. doi: 10.1056/NEJMoa1411087

12. Schmitz JE, Kuroda MJ, Santra S, Sasseville VG, Simon MA, Lifton MA, et al. Control of viremia in simian immunodeficiency virus infection by CD8+ lymphocytes. Science. (1999) 283:857-60.

13. Borrow P, Lewicki H, Hahn BH, Shaw GM, Oldstone MB. Virus-specific CD8+ cytotoxic T-lymphocyte activity associated with control of viremia in primary human immunodeficiency virus type 1 infection. $J$ Virol. (1994) 68:6103-10.

14. Koup RA, Safrit JT, Cao Y, Andrews CA, McLeod G, Borkowsky W, et al. Temporal association of cellular immune responses with the initial control of viremia in primary human immunodeficiency virus type 1 syndrome. $J$ Virol. (1994) 68:4650-5.

15. Goonetilleke N, Liu MK, Salazar-Gonzalez JF, Ferrari G, Giorgi E, Ganusov $\mathrm{VV}$, et al. The first $\mathrm{T}$ cell response to transmitted/founder virus contributes to the control of acute viremia in HIV-1 infection. J Exp Med. (2009) 206:1253-72. doi: 10.1084/jem.20090365

16. Streeck H, Jolin JS, Qi Y, Yassine-Diab B, Johnson RC, Kwon DS, et al. Human immunodeficiency virus type 1-specific CD8+ T-cell responses during primary infection are major determinants of the viral set point and loss of CD4+ T cells. J Virol. (2009) 83:7641-8. doi: 10.1128/JVI.00182-09

17. Ndhlovu ZM, Kamya P, Mewalal N, Kloverpris HN, Nkosi T, Pretorius $\mathrm{K}$, et al. Magnitude and kinetics of $\mathrm{CD} 8+\mathrm{T}$ cell activation during hyperacute HIV infection impact viral set point. Immunity. (2015) 43:591604. doi: 10.1016/j.immuni.2015.08.012

18. Jason Okulicz F, Vincent Marconi C, Michael Landrum L, Wegner S, Weintrob A, Ganesan A, et al. Clinical outcomes of elite controllers, viremic controllers, and long-term nonprogressors in the US Department of Defense HIV Natural History Study. J Infect Dis. (2009) 200:171423. doi: $10.1086 / 646609$

19. Mendoza D, Johnson SA, Peterson BA, Natarajan V, Salgado $M$, Dewar RL, et al. Comprehensive analysis of unique cases with extraordinary control over HIV replication. Blood. (2012) 119:4645-55. doi: 10.1182/blood-2011-10-381996

20. Goulder PJ, Watkins DI. Impact of MHC class I diversity on immune control of immunodeficiency virus replication. Nat Rev Immunol. (2008) 8:619-30. doi: $10.1038 /$ nri2357
21. Pereyra F, Jia X, McLaren PJ, Telenti A, de Bakker PI, Walker BD, et al. The major genetic determinants of HIV-1 control affect HLA class I peptide presentation. Science. (2010) 330:1551-7. doi: 10.1126/science.1195271

22. Betts MR, Nason MC, West SM, De Rosa SC, Migueles SA, Abraham J, et al. HIV nonprogressors preferentially maintain highly functional HIVspecific CD8+ T cells. Blood. (2006) 107:4781-9. doi: 10.1182/blood-2005$12-4818$

23. Rosenberg ES, Billingsley JM, Caliendo AM, Boswell SL, Sax PE, Kalams SA, et al. Vigorous HIV-1-specific CD4+ T cell responses associated with control of viremia. Science. (1997) 278:1447-50.

24. Kosmrlj A, Read EL, Qi Y, Allen TM, Altfeld M, Deeks SG, et al. Effects of thymic selection of the T-cell repertoire on HLA class I-associated control of HIV infection. Nature. (2010) 465:350-4. doi: 10.1038/nature08997

25. Goulder PJ, Brander C, Tang Y, Tremblay C, Colbert RA, Addo MM, et al. Evolution and transmission of stable CTL escape mutations in HIV infection. Nature. (2001) 412:334-8. doi: 10.1038/35085576

26. Carlson JM, Schaefer M, Monaco DC, Batorsky R, Claiborne DT, Prince J, et al. Selection bias at the heterosexual HIV-1 transmission bottleneck. Science. (2014) 345:1254031. doi: 10.1126/science.1254031

27. Lassen KG, Lobritz MA, Bailey JR, Johnston S, Nguyen S, Lee $B$, et al. Elite suppressor-derived HIV-1 envelope glycoproteins exhibit reduced entry efficiency and kinetics. PLoS Pathog. (2009) 5:e1000377. doi: 10.1371/journal.ppat.1000377

28. Miura T, Brockman MA, Brumme ZL, Brumme CJ, Pereyra F, Trocha A, et al. HLA-associated alterations in replication capacity of chimeric NL4-3 viruses carrying gag-protease from elite controllers of human immunodeficiency virus type 1. J Virol. (2009) 83:140-9. doi: 10.1128/JVI.01471-08

29. Ferguson AL, Mann JK, Omarjee S, Ndung'u T, Walker BD, Chakraborty AK. Translating HIV sequences into quantitative fitness landscapes predicts viral vulnerabilities for rational immunogen design. Immunity. (2013) 38:60617. doi: 10.1016/j.immuni.2012.11.022

30. Gaiha G, Rossin EJ, Urbach J, Landeros C, Collins DR, Nwonu C, et al. Structural topology defines protective CD8+ T cell epitopes in the HIV proteome. Science. (2019) 364:480-4. doi: 10.1126/science.aav5095

31. Douek DC, Brenchley JM, Betts MR, Ambrozak DR, Hill BJ, Okamoto Y, et al. HIV preferentially infects HIV-specific CD4+ T cells. Nature. (2002) 417:95-8. doi: 10.1038/417095a

32. Ndhlovu Z, Kazer SW, Nkosi T, Ogunshola F, Muema DM, Anmole G, et al. Augmentation of HIV-specific CD8 $+\mathrm{T}$ cell and CD4+ T cell function by immediate treatment of hyperacute HIV-1 clade C infection. Sci Transl Med. (2019) 11:eaau0528. doi: 10.1126/scitranslmed.aau0528

33. Ehrlich P. Ueber den jetzigen stand der karzinomforschung. Ned. Tijdschr. Geneeskd. (1909) 5:273-90.

34. Old LJ, Boyse EA. Immunology of experimental tumors. Annu Rev Med. (1964) 15:167-86. doi: 10.1146/annurev.me.15.020164.001123

35. Herin M, Lemoine C, Weynants P, Vessiere F, Van Pel A, Knuth A, et al. Production of stable cytolytic T-cell clones directed against autologous human melanoma. Int J Cancer. (1987) 39:390-6.

36. Boon T, Cerottini JC, Van den Eynde B, van der Bruggen P, Van Pel A. Tumor antigens recognized by T lymphocytes. Annu Rev Immunol. (1994) 12:337-65. doi: 10.1146/annurev.iy.12.040194.002005

37. Pages F, Berger A, Camus M, Sanchez-Cabo F, Costes A, Molidor R, et al. Effector memory $\mathrm{T}$ cells, early metastasis, and survival in colorectal cancer. N Engl J Med. (2005) 353:2654-66. doi: 10.1056/NEJMoa051424

38. Zhou J, Dudley ME, Rosenberg SA, Robbins PF. Selective growth, in vitro and in vivo, of individual $\mathrm{T}$ cell clones from tumor-infiltrating lymphocytes obtained from patients with melanoma. J Immunol. (2004) 173:76229. doi: 10.4049/jimmunol.173.12.7622

39. Hellmann MD, Callahan MK, Awad MM, Calvo E, Ascierto PA, Atmaca A, et al. Tumor mutational burden and efficacy of nivolumab monotherapy and in combination with ipilimumab in small-cell lung cancer. Cancer Cell. (2018) 33:853-61.e4. doi: 10.1016/j.ccell.2018.04.001

40. Rizvi NA, Hellmann MD, Snyder A, Kvistborg P, Makarov V, Havel JJ, et al. Cancer immunology. Mutational landscape determines sensitivity to PD-1 blockade in non-small cell lung cancer. Science. (2015) 348:1248. doi: $10.1126 /$ science.aaa 1348

41. Mandal R, Samstein RM, Lee KW, Havel JJ, Wang H, Krishna C, et al. Genetic diversity of tumors with mismatch repair deficiency 
influences anti-PD-1 immunotherapy response. Science. (2019) 364:48591. doi: 10.1126/science.aau0447

42. Bouffet E, Larouche V, Campbell BB, Merico D, de Borja R, Aronson M, et al. Immune checkpoint inhibition for hypermutant glioblastoma multiforme resulting from germline biallelic mismatch repair deficiency. J Clin Oncol. (2016) 34:2206-11. doi: 10.1200/JCO.2016.66.6552

43. Goodman AM, Piccioni D, Kato S, Boichard A, Wang HY, Frampton G, et al. Prevalence of PDL1 amplification and preliminary response to immune checkpoint blockade in solid tumors. JAMA Oncol. (2018) 4:123744. doi: 10.1001/jamaoncol.2018.1701

44. Gibney GT, Weiner LM, Atkins MB. Predictive biomarkers for checkpoint inhibitor-based immunotherapy. Lancet Oncol. (2016) 17:e542-51. doi: 10.1016/S1470-2045(16)30406-5

45. Maude SL, Laetsch TW, Buechner J, Rives S, Boyer M, Bittencourt H, et al. Tisagenlecleucel in children and young adults with B-cell lymphoblastic leukemia. N Engl J Med. (2018) 378:439-48. doi: 10.1056/NEJMoa1709866

46. Neelapu SS, Locke FL, Bartlett NL, Lekakis LJ, Miklos DB, Jacobson CA, et al. Axicabtagene ciloleucel CAR T-cell therapy in refractory large B-cell lymphoma. N Engl J Med. (2017) 377:2531-44. doi: 10.1056/NEJMoa1707447

47. Schuster SJ, Bishop MR, Tam CS, Waller EK, Borchmann P, McGuirk JP, et al. Tisagenlecleucel in adult relapsed or refractory diffuse large B-cell lymphoma. N Engl J Med. (2019) 380:45-56. doi: 10.1056/NEJMoa 1804980

48. Raje N, Berdeja J, Lin Y, Siegel D, Jagannath S, Madduri D, et al. Anti-BCMA CAR T-cell therapy bb2121 in relapsed or refractory multiple myeloma. $N$ Engl J Med. (2019) 380:1726-37. doi: 10.1056/NEJMoa1817226

49. Barber DL, Wherry EJ, Masopust D, Zhu B, Allison JP, Sharpe AH, et al. Restoring function in exhausted CD8 T cells during chronic viral infection. Nature. (2006) 439:682-7. doi: 10.1038/nature04444

50. McLane LM, Abdel-Hakeem MS, Wherry EJ. CD8 T cell exhaustion during chronic viral infection and cancer. Annu Rev Immunol. (2019) 37:45795. doi: 10.1146/annurev-immunol-041015-055318

51. Day CL, Kaufmann DE, Kiepiela P, Brown JA, Moodley ES, Reddy S, et al. PD-1 expression on HIV-specific T cells is associated with T-cell exhaustion and disease progression. Nature. (2006) 443:350-4. doi: 10.1038/nature05115

52. Baitsch L, Baumgaertner P, Devevre E, Raghav SK, Legat A, Barba L, et al. Exhaustion of tumor-specific CD8(+) T cells in metastases from melanoma patients. J Clin Invest. (2011) 121:2350-60. doi: 10.1172/JCI46102

53. Wherry EJ, Kurachi M. Molecular and cellular insights into T cell exhaustion. Nat Rev Immunol. (2015) 15:486-99. doi: 10.1038/nri3862

54. Saeidi A, Zandi K, Cheok YY, Saeidi H, Wong WF, Lee CYQ, et al. Tcell exhaustion in chronic infections: reversing the state of exhaustion and reinvigorating optimal protective immune responses. Front Immunol. (2018) 9:2569. doi: 10.3389/fimmu.2018.02569

55. Doering TA, Crawford A, Angelosanto JM, Paley MA, Ziegler CG, Wherry EJ. Network analysis reveals centrally connected genes and pathways involved in CD8+ T cell exhaustion versus memory. Immunity. (2012) 37:1130-44. doi: 10.1016/j.immuni.2012.08.021

56. Pellegrini M, Calzascia T, Elford AR, Shahinian A, Lin AE, Dissanayake D, et al. Adjuvant IL-7 antagonizes multiple cellular and molecular inhibitory networks to enhance immunotherapies. Nat Med. (2009) 15:52836. doi: $10.1038 / \mathrm{nm} .1953$

57. D'Souza M, Fontenot AP, Mack DG, Lozupone C, Dillon S, Meditz A, et al. Programmed death 1 expression on HIV-specific CD4+ T cells is driven by viral replication and associated with T cell dysfunction. J Immunol. (2007) 179:1979-87. doi: 10.4049/jimmunol.179.3.1979

58. Zhu Y, Ju S, Chen E, Dai S, Li C, Morel P, et al. T-bet and eomesodermin are required for $\mathrm{T}$ cell-mediated antitumor immune responses. J Immunol. (2010) 185:3174-83. doi: 10.4049/jimmunol.1000749

59. Doedens AL, Phan AT, Stradner MH, Fujimoto JK, Nguyen JV, Yang E, et al. Hypoxia-inducible factors enhance the effector responses of CD8+ T cells to persistent antigen. Nature Immunol. (2013) 14:1173-28. doi: 10.1038/ni.2714

60. Man K, Gabriel SS, Liao Y, Gloury R, Preston S, Henstridge DC, et al. Transcription factor IRF4 promotes CD8+ T cell exhaustion and limits the development of memory-like $\mathrm{T}$ cells during chronic infection. Immunity. (2017) 47:1129-41.e5. doi: 10.1016/j.immuni.2017.11.021

61. Stephen TL, Rutkowski MR, Allegrezza MJ, Perales-Puchalt A, Tesone AJ, Svoronos N, et al. Transforming growth factor beta-mediated suppression of antitumor $\mathrm{T}$ cells requires FoxP1 transcription factor expression. Immunity. (2014) 41:427-39. doi: 10.1016/j.immuni.2014.08.012

62. Giordano M, Henin C, Maurizio J, Imbratta C, Bourdely P, Buferne M, et al. Molecular profiling of CD8 $\mathrm{T}$ cells in autochthonous melanoma identifies Maf as driver of exhaustion. EMBO J. (2015) 34:204258. doi: 10.15252/embj.201490786

63. Ahrends T, Spanjaard A, Pilzecker B, Babała N, Bovens A, Xiao Y, et al. $\mathrm{CD} 4+\mathrm{T}$ cell help confers a cytotoxic $\mathrm{T}$ cell effector program including coinhibitory receptor downregulation and increased tissue invasiveness. Immunity. (2017) 47:848-61.e5 doi: 10.1016/j.immuni.2017. 10.009

64. Streeck H, D'Souza MP, Littman DR, Crotty S. Harnessing CD4(+) T cell responses in HIV vaccine development. Nat Med. (2013) 19:1439. doi: $10.1038 / \mathrm{nm} .3054$

65. Lichterfeld M, Kaufmann DE, Yu XG, Mui SK, Addo MM, Johnston MN, et al. Loss of HIV-1-specific CD8+ T cell proliferation after acute HIV-1 infection and restoration by vaccine-induced HIV-1-specific CD4+ T cells. $J$ Exp Med. (2004) 200:701-12. doi: 10.1084/jem.20041270

66. Avila-Rios S, Carlson JM, John M, Mallal S, Brumme ZL. Clinical and evolutionary consequences of HIV adaptation to HLA: implications for vaccine and cure. Curr Opin HIV AIDS. (2019) 14:194-204. doi: 10.1097/COH.0000000000000541

67. Schreiber RD, Old LJ, Smyth MJ. Cancer immunoediting: integrating immunity's roles in cancer suppression and promotion. Science. (2011) 331:1565-70. doi: 10.1126/science. 1203486

68. McMichael AJ, Borrow P, Tomaras GD, Goonetilleke N, Haynes BF. The immune response during acute HIV-1 infection: clues for vaccine development. Nat Rev Immunol. (2010) 10:11-23. doi: 10.1038/nri2674

69. Kawashima Y, Pfafferott K, Frater J, Matthews P, Payne R, Addo M, et al. Adaptation of HIV-1 to human leukocyte antigen class I. Nature. (2009) 458:641-5. doi: 10.1038/nature07746

70. Deng K, Pertea M, Rongvaux A, Wang L, Durand CM, Ghiaur G, et al. Broad CTL response is required to clear latent HIV-1 due to dominance of escape mutations. Nature. (2015) 517:381-5. doi: 10.1038/nature14053

71. Dunn GP, Ikeda H, Bruce AT, Koebel C, Uppaluri R, Bui J, et al. Interferon- $\gamma$ and cancer immunoediting. Immunol Res. (2005) 32:23145. doi: 10.1385/IR:32:1-3:231

72. Barouch DH, Tomaka FL, Wegmann F, Stieh DJ, Alter G, Robb $\mathrm{ML}$, et al. Evaluation of a mosaic HIV-1 vaccine in a multicentre, randomised, double-blind, placebo-controlled, phase 1/2a clinical trial (APPROACH) and in rhesus monkeys (NHP 13-19). Lancet. (2018) 392:23243. doi: 10.1016/S0140-6736(18)31364-3

73. Beavis PA, Henderson MA, Giuffrida L, Mills JK, Sek K, Cross RS, et al. Targeting the adenosine $2 \mathrm{~A}$ receptor enhances chimeric antigen receptor $\mathrm{T}$ cell efficacy. J Clin Invest. (2017) 127:929-41. doi: 10.1172/JCI89455

74. Munn DH, Mellor AL. IDO in the tumor microenvironment: inflammation, counter-regulation, and tolerance. Trends Immunol. (2016) 37:193207. doi: 10.1016/j.it.2016.01.002

75. Spranger S, Spaapen RM, Zha Y, Williams J, Meng Y, Ha TT, et al. Up-regulation of PD-L1, IDO, and T(regs) in the melanoma tumor microenvironment is driven by CD8(+) T cells. Sci Transl Med. (2013) 5:200ra116. doi: 10.1126/scitranslmed.3006504

76. Spranger S, Bao R, Gajewski TF. Melanoma-intrinsic beta-catenin signalling prevents anti-tumour immunity. Nature. (2015) 523:2315. doi: 10.1038 /nature14404

77. Peranzoni E, Lemoine J, Vimeux L, Feuillet V, Barrin S, Kantari-Mimoun $\mathrm{C}$, et al. Macrophages impede CD8 T cells from reaching tumor cells and limit the efficacy of anti-PD-1 treatment. Proc Natl Acad Sci USA. (2018) 115:E4041-50. doi: 10.1073/pnas. 1720948115

78. Mariathasan S, Turley SJ, Nickles D, Castiglioni A, Yuen K, Wang Y, et al. TGF $\beta$ attenuates tumour response to PD-L1 blockade by contributing to exclusion of T cells. Nature. (2018) 554:544-8. doi: 10.1038/nature25501

79. Dimopoulos Y, Moysi E, Petrovas C. The lymph node in HIV pathogenesis. Curr HIV/AIDS Rep. (2017) 14:133-40. doi: 10.1007/s11904-017-0359-7

80. Boritz EA, Douek DC. Perspectives on human immunodeficiency virus (HIV) cure: HIV persistence in tissue. J Infect Dis. (2017) 215(suppl_3):S12833. doi: 10.1093/infdis/jix005 
81. Fletcher AL, Acton SE, Knoblich K. Lymph node fibroblastic reticular cells in health and disease. Nat Rev Immunol. (2015) 15:350-61. doi: 10.1038/nri3846

82. Fazilleau N, McHeyzer-Williams LJ, Rosen H, McHeyzer-Williams MG. The function of follicular helper $\mathrm{T}$ cells is regulated by the strength of $\mathrm{T}$ cell antigen receptor binding. Nat Immunol. (2009) 10:37584. doi: 10.1038/ni.1704

83. Tubo NJ, Jenkins MK. TCR signal quantity and quality in CD4 T cell differentiation. Trends Immunol. (2014) 35:5916. doi: 10.1016/j.it.2014.09.008

84. Shi J, Hou S, Fang Q, Liu X, Liu X, Qi H. PD-1 controls follicular $\mathrm{T}$ helper cell positioning and function. Immunity. (2018) 49:264-74.e4. doi: 10.1016/j.immuni.2018. 06.012

85. Rodda LB, Lu E, Bennett ML, Sokol CL, Wang X, Luther $\mathrm{SA}$, et al. Single-cell RNA sequencing of lymph node stromal cells reveals niche-associated heterogeneity. Immunity. (2018) 48:1014-28.e6. doi: 10.1016/j.immuni.2018.04.006

86. Knoblich N, Gundel F, Bruckmann C, Becker-Sadzio J, Frischholz C, Nieratschker V. DNA methylation of APBA3 and MCF2 in borderline personality disorder: potential biomarkers for response to psychotherapy. Eur Neuropsychopharmacol. (2018) 28:252-63. doi: 10.1016/j.euroneuro.2017.12.010

87. Crotty S. T follicular helper cell biology: a decade of discovery and diseases. Immunity. (2019) 50:1132-48. doi: 10.1016/j.immuni.2019.04.011

88. Lindqvist M, van Lunzen J, Soghoian DZ, Kuhl BD, Ranasinghe S, Kranias $\mathrm{G}$, et al. Expansion of HIV-specific T follicular helper cells in chronic HIV infection. J Clin Invest. (2012) 122:3271-80. doi: 10.1172/JCI64314

89. Xu Y, Weatherall C, Bailey M, Alcantara S, De Rose R, Estaquier J, et al. Simian immunodeficiency virus infects follicular helper CD4 T cells in lymphoid tissues during pathogenic infection of pigtail macaques. $J$ Virol. (2013) 87:3760-73. doi: 10.1128/JVI.02497-12

90. Mylvaganam GH, Velu V, Hong JJ, Sadagopal S, Kwa S, Basu R, et al. Diminished viral control during simian immunodeficiency virus infection is associated with aberrant PD-1hi CD4 T cell enrichment in the lymphoid follicles of the rectal mucosa. J Immunol. (2014) 193:452736. doi: 10.4049/jimmunol.1401222

91. Perreau M, Savoye AL, De Crignis E, Corpataux JM, Cubas R, Haddad EK, et al. Follicular helper T cells serve as the major CD4 T cell compartment for HIV-1 infection, replication, and production. J Exp Med. (2013) 210:14356. doi: 10.1084/jem.20121932

92. Connick E, Mattila T, Folkvord JM, Schlichtemeier R, Meditz AL, Ray MG, et al. CTL fail to accumulate at sites of HIV-1 replication in lymphoid tissue. J Immunol. (2007) 178:6975-83. doi: 10.4049/jimmunol.178. 11.6975

93. Zeng M, Southern PJ, Reilly CS, Beilman GJ, Chipman JG, Schacker TW, et al. Lymphoid tissue damage in HIV-1 infection depletes naive T cells and limits T cell reconstitution after antiretroviral therapy. PLoS Pathog. (2012) 8:e1002437. doi: 10.1371/journal.ppat.1002437

94. Schacker TW, Reilly C, Beilman GJ, Taylor J, Skarda D, Krason D, et al. Amount of lymphatic tissue fibrosis in HIV infection predicts magnitude of HAART-associated change in peripheral CD4 cell count. AIDS. (2005) 19:2169-71. doi: 10.1097/01.aids.0000194801.51422.03

95. Schacker TW, Brenchley JM, Beilman GJ, Reilly C, Pambuccian SE, Taylor $\mathrm{J}$, et al. Lymphatic tissue fibrosis is associated with reduced numbers of naive CD4+ T cells in human immunodeficiency virus type 1 infection. Clin Vaccine Immunol. (2006) 13:556-60. doi: 10.1128/CVI.13.5.556-560.2006

96. Nilsson J, Boasso A, Velilla PA, Zhang R, Vaccari M, Franchini G, et al. HIV-1-driven regulatory T-cell accumulation in lymphoid tissues is associated with disease progression in HIV/AIDS. Blood. (2006) 108:380817. doi: 10.1182/blood-2006-05-021576

97. Estes JD, Li Q, Reynolds MR, Wietgrefe S, Duan L, Schacker T, et al. Premature induction of an immunosuppressive regulatory $\mathrm{T}$ cell response during acute simian immunodeficiency virus infection. J Infect Dis. (2006) 193:703-12. doi: 10.1086/500368

98. Estes JD, Wietgrefe S, Schacker T, Southern P, Beilman G, Reilly C, et al. Simian immunodeficiency virus-induced lymphatic tissue fibrosis is mediated by transforming growth factor $\beta 1$-positive regulatory $\mathrm{T}$ cells and begins in early infection. J Infect Dis. (2007) 195:551-61. doi: 10.1086/510852
99. Aras S, Zaidi MR. TAMeless traitors: macrophages in cancer progression and metastasis. Br J Cancer. (2017) 117:1583-91. doi: 10.1038/bjc.2017.356

100. Spranger S, Gajewski TF. Impact of oncogenic pathways on evasion of antitumour immune responses. Nat Rev Cancer. (2018) 18:139147. doi: $10.1038 / \mathrm{nrc} .2017 .117$

101. Yue C, Shen S, Deng J, Priceman SJ, Li W, Huang A, et al. STAT3 in CD8+ $\mathrm{T}$ cells inhibits their tumor accumulation by downregulating CXCR3/CXCL10 axis. Cancer Immunol Res. (2015) 3:864-70. doi: 10.1158/2326-6066.CIR-15-0014

102. Ciucci T, Vacchio MS, Bosselut R. A STAT3-dependent transcriptional circuitry inhibits cytotoxic gene expression in T cells. Proc Natl Acad Sci USA. (2017) 114:13236-41. doi: 10.1073/pnas.1711160114

103. Nixon NA, Blais N, Ernst S, Kollmannsberger C, Bebb G, Butler M, et al. Current landscape of immunotherapy in the treatment of solid tumours, with future opportunities and challenges. Curr Oncol. (2018) 25:e37384. doi: $10.3747 /$ co. 25.3840

104. He R, Hou S, Liu C, Zhang A, Bai Q, Han M, et al. Follicular CXCR5expressing CD8+ T cells curtail chronic viral infection. Nature. (2016) 537:412-28. doi: 10.1038/nature19317

105. Mylvaganam GH, Rios D, Abdelaal HM, Iyer S, Tharp G, Mavinger $\mathrm{M}$, et al. Dynamics of SIV-specific CXCR5+ CD8 T cells during chronic SIV infection. Proc Natl Acad Sci USA. (2017) 114:197681. doi: $10.1073 /$ pnas. 1621418114

106. Reuter MA, Del Rio Estrada PM, Buggert M, Petrovas C, Ferrando-Martinez $\mathrm{S}$, Nguyen S, et al. HIV-specific CD8 $(+) \mathrm{T}$ cells exhibit reduced and differentially regulated cytolytic activity in lymphoid tissue. Cell Rep. (2017) 21:3458-70. doi: 10.1016/j.celrep.2017.11.075

107. Chu F, Li HS, Liu X, Cao J, Ma W, Ma Y, et al. CXCR5(+)CD8(+) T cells are a distinct functional subset with an antitumor activity. Leukemia. (2019). doi: 10.1038/s41375-019-0464-2. [Epub ahead of print].

108. Perdomo-Celis F, Taborda NA, Rugeles MT. Circulating CXCR5expressing CD8+ T-cells are major producers of IL-21 and associate with limited HIV replication. J Acquir Immune Defic Syndr. (2018) 78:473-82. doi: 10.1097/QAI.0000000000001700

109. Laurent C, Muller S, Do C, Al-Saati T, Allart S, Larocca LM, et al. Distribution, function, and prognostic value of cytotoxic T lymphocytes in follicular lymphoma: a 3-D tissue-imaging study. Blood. (2011) 118:53719. doi: 10.1182/blood-2011-04-345777

110. Gratton S, Yao XJ, Venkatesan S, Cohen EA, Sekaly RP. Molecular analysis of the cytoplasmic domain of CD4: overlapping but noncompetitive requirement for lck association and down-regulation by Nef. J Immunol. (1996) 157:3305-11.

111. Loffek S. Transforming of the tumor microenvironment: implications for TGF- $\beta$ inhibition in the context of immune-checkpoint therapy. $J$ Oncol. (2018) 2018:9732939. doi: 10.1155/2018/9732939

112. Batlle E, Massague J. Transforming growth factor-beta signaling in immunity and cancer. Immunity. (2019) 50:924-40. doi: 10.1016/j.immuni.2019.03.024

113. Hutter G, Nowak D, Mossner M, Ganepola S, Mussig A, Allers K, et al. Longterm control of HIV by CCR5 delta32/delta32 stem-cell transplantation. $N$ Engl J Med. (2009) 360:692-8. doi: 10.1056/NEJMoa0802905

114. Lederman MM, Pike E. Ten years HIV free: an interview with "The Berlin Patient," Timothy Ray Brown. Pathog Immun. (2017) 2:42230. doi: 10.20411/pai.v2i3.226

115. Gupta K, Hudgens M, Corey L, McElrath MJ, Weinhold K, Montefiori DC, et al. Safety and immunogenicity of a high-titered canarypox vaccine in combination with rgp120 in a diverse population of HIV-1-uninfected adults: AIDS vaccine evaluation group protocol 022A. J Acquir Immune Defic Syndr. (2002) 29:254-61. doi: 10.1097/00042560-200203010-00005

116. Kordelas L, Verheyen J, Beelen DW, Horn PA, Heinold A, Kaiser R, et al. Shift of HIV tropism in stem-cell transplantation with CCR5 Delta32 mutation. $N$ Engl J Med. (2014) 371:880-2. doi: 10.1056/NEJMc1405805

117. Gyurkocza B, Sandmaier BM. Conditioning regimens for hematopoietic cell transplantation: one size does not fit all. Blood. (2014) 124:34453. doi: 10.1182/blood-2014-02-514778

118. Patsoukis N, Brown J, Petkova V, Liu F, Li L, Boussiotis VA. Selective effects of PD-1 on Akt and Ras pathways regulate molecular components of the cell cycle and inhibit T cell proliferation. Sci Signal. (2012) 5:ra46. doi: 10.1126/scisignal.2002796 
119. Chemnitz JM, Parry RV, Nichols KE, June CH, Riley JL. SHP-1 and SHP-2 associate with immunoreceptor tyrosine-based switch motif of programmed death 1 upon primary human $\mathrm{T}$ cell stimulation, but only receptor ligation prevents T cell activation. J Immunol. (2004) 173:94554. doi: 10.4049/jimmunol.173.2.945

120. Hodi FS, O'Day SJ, McDermott DF, Weber RW, Sosman JA, Haanen JB, et al. Improved survival with ipilimumab in patients with metastatic melanoma. $N$ Engl J Med. (2010) 363:711-23. doi: 10.1056/NEJMoa1003466

121. Topalian SL, Sznol M, McDermott DF, Kluger HM, Carvajal RD, Sharfman $\mathrm{WH}$, et al. Survival, durable tumor remission, and long-term safety in patients with advanced melanoma receiving nivolumab. J Clin Oncol. (2014) 32:1020-30. doi: 10.1200/JCO.2013.53.0105

122. McDermott DF, Drake CG, Sznol M, Choueiri TK, Powderly JD, Smith DC, et al. Survival, durable response, and long-term safety in patients with previously treated advanced renal cell carcinoma receiving nivolumab. J Clin Oncol. (2015) 33:2013-20. doi: 10.1200/JCO.2014.58.1041

123. Trujillo JA, Sweis RF, Bao R, Luke JJ. T cell-inflamed versus non-T cellinflamed tumors: a conceptual framework for cancer immunotherapy drug development and combination therapy selection. Cancer Immunol Res. (2018) 6:990-1000. doi: 10.1158/2326-6066.CIR-18-0277

124. Tumeh PC, Harview CL, Yearley JH, Shintaku IP, Taylor EJ, Robert L, et al. PD-1 blockade induces responses by inhibiting adaptive immune resistance. Nature. (2014) 515:568-71. doi: 10.1038/nature13954

125. Escudier B, Motzer RJ, Sharma P, Wagstaff J, Plimack ER, Hammers HJ, et al. Treatment beyond progression in patients with advanced renal cell carcinoma treated with nivolumab in checkmate 025. Eur Urol. (2017) 72:368-76. doi: 10.1016/j.eururo.2017.03.037

126. Chen Y, Liu Q, Chen Z, Wang Y, Yang W, Hu Y, et al. PDL1 expression and tumor mutational burden status for prediction of response to chemotherapy and targeted therapy in non-small cell lung cancer. J Exp Clin Cancer Res. (2019) 38:193. doi: 10.1186/s13046-0191192-1

127. Overman MJ, McDermott R, Leach JL, Lonardi S, Lenz HJ, Morse MA, et al. Nivolumab in patients with metastatic DNA mismatch repair-deficient or microsatellite instability-high colorectal cancer (CheckMate 142): an open-label, multicentre, phase 2 study. Lancet Oncol. (2017) 18:118291. doi: 10.1016/S1470-2045(17)30422-9

128. Herbst RS, Soria JC, Kowanetz M, Fine GD, Hamid O, Gordon MS, et al. Predictive correlates of response to the anti-PD-L1 antibody MPDL3280A in cancer patients. Nature. (2014) 515:563-7. doi: 10.1038/nature14011

129. Connick E, Folkvord JM, Lind KT, Rakasz EG, Miles B, Wilson NA, et al. Compartmentalization of simian immunodeficiency virus replication within secondary lymphoid tissues of rhesus macaques is linked to disease stage and inversely related to localization of virus-specific CTL. J Immunol. (2014) 193:5613-25. doi: 10.4049/jimmunol.1401161

130. Im SJ, Hashimoto M, Gerner MY, Lee J, Kissick HT, Burger MC, et al. Defining CD8 $+\mathrm{T}$ cells that provide the proliferative burst after PD-1 therapy. Nature. (2016) 537:417-21. doi: 10.1038/nature19330

131. Velu V, Titanji K, Zhu B, Husain S, Pladevega A, Lai L, et al. Enhancing SIV-specific immunity in vivo by PD-1 blockade. Nature. (2009) 458:20610. doi: $10.1038 /$ nature 07662

132. Finnefrock AC, Tang A, Li F, Freed DC, Feng M, Cox KS, et al. PD-1 blockade in rhesus macaques: impact on chronic infection and prophylactic vaccination. J Immunol. (2009) 182:980-7. doi: 10.4049/jimmunol.182. 2.980

133. Dyavar Shetty R, Velu V, Titanji K, Bosinger SE, Freeman GJ, Silvestri G, et al. PD-1 blockade during chronic SIV infection reduces hyperimmune activation and microbial translocation in rhesus macaques. J Clin Invest. (2012) 122:1712-6. doi: 10.1172/JCI60612

134. Le Garff G, Samri A, Lambert-Niclot S, Even S, Lavole A, Cadranel $\mathrm{J}$, et al. Transient HIV-specific $\mathrm{T}$ cells increase and inflammation in an HIV-infected patient treated with nivolumab. AIDS. (2017) 31:104851. doi: 10.1097/QAD.0000000000001429

135. Heppt MV, Schlaak M, Eigentler TK, Kahler KC, Kiecker F, Loquai $\mathrm{C}$, et al. Checkpoint blockade for metastatic melanoma and Merkel cell carcinoma in HIV-positive patients. Ann Oncol. (2017) 28:31046. doi: 10.1093/annonc/mdx538
136. Banga R, Procopio FA, Noto A, Pollakis G, Cavassini M, Ohmiti K, et al. PD-1(+) and follicular helper T cells are responsible for persistent HIV1 transcription in treated aviremic individuals. Nat Med. (2016) 22:75461. doi: $10.1038 / \mathrm{nm} .4113$

137. Fukazawa Y, Lum R, Okoye AA, Park H, Matsuda K, Bae JY, et al. B cell follicle sanctuary permits persistent productive simian immunodeficiency virus infection in elite controllers. Nat Med. (2015) 21:132-9. doi: 10.1038/nm.3781

138. Chomont N, El-Far M, Ancuta P, Trautmann L, Procopio FA, YassineDiab B, et al. HIV reservoir size and persistence are driven by $\mathrm{T}$ cell survival and homeostatic proliferation. Nat Med. (2009) 15:893900. doi: 10.1038/nm.1972

139. Bui JK, Cyktor JC, Fyne E, Campellone S, Mason SW, Mellors JW. Blockade of the PD-1 axis alone is not sufficient to activate HIV-1 virion production from CD4+ T cells of individuals on suppressive ART. PLoS ONE. (2019) 14:e0211112. doi: 10.1371/journal.pone.0211112

140. Evans VA, van der Sluis RM, Solomon A, Dantanarayana A, McNeil C, Garsia R, et al. Programmed cell death-1 contributes to the establishment and maintenance of HIV-1 latency. AIDS. (2018) 32:14917. doi: 10.1097/QAD.0000000000001849

141. Fromentin R, DaFonseca S, Costiniuk CT, El-Far M, Procopio FA, Hecht FM, et al. PD-1 blockade potentiates HIV latency reversal ex vivo in CD4(+) T cells from ART-suppressed individuals. Nat Commun. (2019) 10:814. doi: 10.1038/s41467-019-08798-7

142. Mylvaganam GH, Chea LS, Tharp GK, Hicks S, Velu V, Iyer $\mathrm{SS}$, et al. Combination anti-PD-1 and antiretroviral therapy provides therapeutic benefit against SIV. JCI Insight. (2018) 3:122940. doi: 10.1172/jci.insight. 122940

143. McGary CS, Deleage C, Harper J, Micci L, Ribeiro SP, Paganini S, et al. CTLA4(+)PD-1(-) memory CD4(+) T cells critically contribute to viral persistence in antiretroviral therapy-suppressed, SIV-infected rhesus macaques. Immunity. (2017) 47:776-88.e5. doi: 10.1016/j.immuni.2017.09.018

144. Colston E, Grasela D, Gardiner D, Bucy RP, Vakkalagadda B, Korman $\mathrm{AJ}$, et al. An open-label, multiple ascending dose study of the antiCTLA-4 antibody ipilimumab in viremic HIV patients. PLOS ONE. (2018) 13:e0198158. doi: 10.1371/journal.pone.0198158

145. Hopkins AM, Rowland A, Kichenadasse G, Wiese MD, Gurney H, McKinnon RA, et al. Predicting response and toxicity to immune checkpoint inhibitors using routinely available blood and clinical markers. $\mathrm{Br}$ J Cancer. (2017) 117:913-20. doi: 10.1038/bjc.2017.274

146. De Velasco G, Je Y, Bosse D, Awad MM, Ott PA, Moreira RB, et al. Comprehensive meta-analysis of key immune-related adverse events from CTLA-4 and PD-1/PD-L1 inhibitors in cancer patients. Cancer Immunol Res. (2017) 5:312-8. doi: 10.1158/2326-6066.CIR-16-0237

147. Rapisuwon S, Izar B, Batenchuk C, Avila A, Mei S, Sorger P, et al. Exceptional response and multisystem autoimmune-like toxicities associated with the same $\mathrm{T}$ cell clone in a patient with uveal melanoma treated with immune checkpoint inhibitors. J Immunother Cancer. (2019) 7:61. doi: 10.1186/s40425-019-0533-0

148. Rogado J, Sanchez-Torres JM, Romero-Laorden N, Ballesteros AI, PachecoBarcia V, Ramos-Levi A, et al. Immune-related adverse events predict the therapeutic efficacy of anti-PD-1 antibodies in cancer patients. Eur J Cancer. (2019) 109:21-7. doi: 10.1016/j.ejca.2018.10.014

149. June $\mathrm{CH}$, Sadelain M. Chimeric antigen receptor therapy. $N$ Engl J Med. (2018) 379:64-73. doi: 10.1056/NEJMra1706169

150. O’Rourke DM, Nasrallah MP, Desai A, Melenhorst JJ, Mansfield K, Morrissette JJD, et al. A single dose of peripherally infused EGFRvIIIdirected CAR $\mathrm{T}$ cells mediates antigen loss and induces adaptive resistance in patients with recurrent glioblastoma. Sci Transl Med. (2017) 9:eaaa0984. doi: 10.1126/scitranslmed.aaa0984

151. Maude SL, Frey N, Shaw PA, Aplenc R, Barrett DM, Bunin NJ, et al. Chimeric antigen receptor T cells for sustained remissions in leukemia. $N$ Engl J Med. (2014) 371:1507-17. doi: 10.1056/NEJMoa1407222

152. Kawalekar OU, O’Connor RS, Fraietta JA, Guo L, McGettigan SE, et al. Distinct signaling of coreceptors regulates specific metabolism pathways and impacts memory development in CAR T cells. Immunity. (2016) 44:712. doi: 10.1016/j.immuni.2016.02.023 
153. Gardner R, Wu D, Cherian S, Fang M, Hanafi LA, Finney O, et al. Acquisition of a CD19-negative myeloid phenotype allows immune escape of MLLrearranged B-ALL from CD19 CAR-T-cell therapy. Blood. (2016) 127:240610. doi: 10.1182/blood-2015-08-665547

154. Cherkassky L, Morello A, Villena-Vargas J, Feng Y, Dimitrov DS, Jones $\mathrm{DR}$, et al. Human CAR T cells with cell-intrinsic PD-1 checkpoint blockade resist tumor-mediated inhibition. J Clin Invest. (2016) 126:313044. doi: 10.1172/JCI83092

155. Yeku OO, Purdon TJ, Koneru M, Spriggs D, Brentjens RJ. Armored CAR $T$ cells enhance antitumor efficacy and overcome the tumor microenvironment. Sci Rep. (2017) 7:10541. doi: 10.1038/s41598-017-10940-8

156. Hu B, Ren J, Luo Y, Keith B, Young RM, Scholler J, et al. Augmentation of antitumor immunity by human and mouse CAR T cells secreting IL-18. Cell Rep. (2017) 20:3025-33. doi: 10.1016/j.celrep.2017.09.002

157. Rafiq S, Yeku OO, Jackson HJ, Purdon TJ, van Leeuwen DG, Drakes DJ, et al. Targeted delivery of a PD-1-blocking scFv by CAR-T cells enhances anti-tumor efficacy in vivo. Nat Biotechnol. (2018) 36:84756. doi: 10.1038/nbt.4195

158. Adachi K, Kano Y, Nagai T, Okuyama N, Sakoda Y, Tamada K. IL-7 and CCL19 expression in CAR-T cells improves immune cell infiltration and CAR-T cell survival in the tumor. Nat Biotechnol. (2018) 36:34651. doi: $10.1038 /$ nbt.4086

159. Yang OO, Tran AC, Kalams SA, Johnson RP, Roberts MR, Walker BD. Lysis of HIV-1-infected cells and inhibition of viral replication by universal receptor T cells. Proc Natl Acad Sci USA. (1997) 94:11478-83.

160. Deeks SG, Wagner B, Anton PA, Mitsuyasu RT, Scadden DT, Huang $\mathrm{C}$, et al. A phase II randomized study of HIV-specific T-cell gene therapy in subjects with undetectable plasma viremia on combination antiretroviral therapy. Mol Ther. (2002) 5:788-97. doi: 10.1006/mthe.200 2.0611

161. Scholler J, Brady TL, Binder-Scholl G, Hwang WT, Plesa G, Hege KM, et al. Decade-long safety and function of retroviralmodified chimeric antigen receptor $\mathrm{T}$ cells. Sci Transl Med. (2012) 4:132ra53. doi: 10.1126/scitranslmed.3003761

162. Caskey M, Klein F, Lorenzi JC, Seaman MS, West AP Jr, Buckley N, et al. Viraemia suppressed in HIV-1-infected humans by broadly neutralizing antibody 3BNC117. Nature. (2015) 522:487-91. doi: 10.1038/nature 14411

163. Lu CL, Murakowski DK, Bournazos S, Schoofs T, Sarkar D, HalperStromberg A, et al. Enhanced clearance of HIV-1-infected cells by broadly neutralizing antibodies against HIV-1 in vivo. Science. (2016) 352:10014. doi: 10.1126/science.aaf1279

164. Bar KJ, Sneller MC, Harrison LJ, Justement JS, Overton ET, Petrone ME, Salantes DB, Seamon CA, et al. Effect of HIV antibody VRC01 on viral rebound after treatment interruption. N Engl J Med. (2016) 375:203750. doi: 10.1056/NEJMoa1608243

165. Scheid JF, Horwitz JA, Bar-On Y, Kreider EF, Lu CL, Lorenzi JC, et al. HIV1 antibody 3 BNC117 suppresses viral rebound in humans during treatment interruption. Nature. (2016) 535:556-60. doi: 10.1038/nature18929

166. Chun TW, Murray D, Justement JS, Blazkova J, Hallahan CW, Fankuchen O, et al. Broadly neutralizing antibodies suppress HIV in the persistent viral reservoir. Proc Natl Acad Sci USA. (2014) 111:13151-6. doi: 10.1073/pnas.1414148111

167. Masiero S, Del Vecchio C, Gavioli R, Mattiuzzo G, Cusi MG, Micheli $\mathrm{L}$, et al. T-cell engineering by a chimeric T-cell receptor with antibodytype specificity for the HIV-1 gp120. Gene Ther. (2005) 12:299310. doi: $10.1038 /$ sj.gt.3302413

168. Zhen A, Kamata M, Rezek V, Rick J, Levin B, Kasparian S, et al. HIV-specific immunity derived from chimeric antigen receptor-engineered stem cells. Mol Ther. (2015) 23:1358-67. doi: 10.1038/mt.2015.102

169. Hale M, Mesojednik T, Romano Ibarra GS, Sahni J, Bernard A, Sommer K, et al. Engineering HIV-resistant, anti-HIV chimeric antigen receptor T cells. Mol Ther. (2017) 25:570-9. doi: 10.1016/j.ymthe.2016. 12.023

170. Ayala VI, Deleage C, Trivett MT, Jain S, Coren LV, Breed MW, et al. CXCR5-dependent entry of CD8 T cells into rhesus macaque
B-cell follicles achieved through T-cell engineering. J Virol. (2017) 91:e02507. doi: 10.1128/JVI.02507-16

171. Haran KP, Hajduczki A, Pampusch MS, Mwakalundwa G, VargasInchaustegui DA, Rakasz EG, et al. Simian immunodeficiency virus (SIV)-specific chimeric antigen receptor-T cells engineered to target B cell follicles and suppress SIV replication. Front Immunol. (2018) 9:492. doi: 10.3389/fimmu.2018.00492

172. Stenner F, Renner C. Cancer immunotherapy and the immune response in follicular lymphoma. Front Oncol. (2018) 8:219. doi: 10.3389/fonc.2018.00219

173. Chmielewski M, Abken H. CAR T cells releasing IL-18 convert to T-bet(high) FoxO1(low) effectors that exhibit augmented activity against advanced solid tumors. Cell Rep. (2017) 21:3205-19. doi: 10.1016/j.celrep.2017. 11.063

174. Pegram HJ, Purdon TJ, van Leeuwen DG, Curran KJ, Giralt SA, Barker JN, et al. IL-12-secreting CD19-targeted cord blood-derived T cells for the immunotherapy of B-cell acute lymphoblastic leukemia. Leukemia. (2015) 29:415-22. doi: 10.1038/leu.2014.215

175. Hurton LV, Singh H, Najjar AM, Switzer KC, Mi T, Maiti S, et al. Tethered IL-15 augments antitumor activity and promotes a stem-cell memory subset in tumor-specific T cells. Proc Natl Acad Sci USA. (2016) 113:E778897. doi: 10.1073/pnas.1610544113

176. Foster AE, Dotti G, Lu A, Khalil M, Brenner MK, Heslop $\mathrm{HE}$, et al. Antitumor activity of EBV-specific $\mathrm{T}$ lymphocytes transduced with a dominant negative TGF- $\beta$ receptor. J Immunother. (2008) 31:500-5. doi: 10.1097/CJI.0b013e31817 $7092 \mathrm{~b}$

177. Kloss CC, Lee J, Zhang A, Chen F, Melenhorst JJ, Lacey SF, et al. Dominantnegative TGF- $\beta$ receptor enhances PSMA-targeted human CAR T cell proliferation and augments prostate cancer eradication. Mol Ther. (2018) 26:1855-66. doi: 10.1016/j.ymthe.2018.05.003

178. Caskey M, Schoofs T, Gruell H, Settler A, Karagounis T, Kreider EF, et al. Antibody 10-1074 suppresses viremia in HIV-1-infected individuals. Nat Med. (2017) 23:185-91. doi: 10.1038/nm.4268

179. Mendoza P, Gruell H, Nogueira L, Pai JA, Butler AL, Millard K, et al. Combination therapy with anti-HIV-1 antibodies maintains viral suppression. Nature. (2018) 561:479-84. doi: 10.1038/s41586-018-0531-2

180. Keskin DB, Anandappa AJ, Sun J, Tirosh I, Mathewson ND, $\mathrm{Li} S$, et al. Neoantigen vaccine generates intratumoral $\mathrm{T}$ cell responses in phase Ib glioblastoma trial. Nature. (2019) 565:234-9. doi: 10.1038/s41586-018-0792-9

181. Coley WB. The treatment of inoperable sarcoma by bacterial toxins (the mixed toxins of the Streptococcus erysipelas and the Bacillus prodigiosus). Proc R Soc Med. (1910) 3:1-48.

182. Kantoff PW, Higano CS, Shore ND, Berger ER, Small EJ, Penson DF, et al. Sipuleucel-T immunotherapy for castration-resistant prostate cancer. $N$ Engl J Med. (2010) 363:411-22. doi: 10.1056/NEJMoa1001294

183. Schirrmacher V. Clinical trials of antitumor vaccination with an autologous tumor cell vaccine modified by virus infection: improvement of patient survival based on improved antitumor immune memory. Cancer Immunol Immunother. (2005) 54:587-98. doi: 10.1007/s00262-004-0602-0

184. Steiner HH, Bonsanto MM, Beckhove P, Brysch M, Geletneky K, Ahmadi $\mathrm{R}$, et al. Antitumor vaccination of patients with glioblastoma multiforme: a pilot study to assess feasibility, safety, and clinical benefit. J Clin Oncol. (2004) 22:4272-81. doi: 10.1200/JCO.2004.09.038

185. Vermaelen K. Vaccine strategies to improve anti-cancer cellular immune responses. Front Immunol. (2019) 10:8. doi: 10.3389/fimmu.2019.00008

186. Lutz E, Yeo CJ, Lillemoe KD, Biedrzycki B, Kobrin B, Herman J, et al. A lethally irradiated allogeneic granulocyte-macrophage colony stimulating factor-secreting tumor vaccine for pancreatic adenocarcinoma. A Phase II trial of safety, efficacy, and immune activation. Ann Surg. (2011) 253:32835. doi: 10.1097/SLA.0b013e3181fd271c

187. Laheru D, Lutz E, Burke J, Biedrzycki B, Solt S, Onners B, et al. Allogeneic granulocyte macrophage colony-stimulating factor-secreting tumor immunotherapy alone or in sequence with cyclophosphamide for metastatic pancreatic cancer: a pilot study of safety, feasibility, and immune activation. Clin Cancer Res. (2008) 14:1455-63. doi: 10.1158/1078-0432.CCR-07-0371 
188. Coelho AV, de Moura RR, Kamada AJ, da Silva RC, Guimaraes RL, Brandao LA, et al. Dendritic cell-based immunotherapies to fight HIV: how far from a success story? A systematic review and meta-analysis. Int J Mol Sci. (2016) 17:1985. doi: 10.3390/ijms17121985

189. Levy Y, Thiebaut R, Montes M, Lacabaratz C, Sloan L, King B, et al. Dendritic cell-based therapeutic vaccine elicits polyfunctional HIV-specific T-cell immunity associated with control of viral load. Eur J Immunol. (2014) 44:2802-10. doi: 10.1002/eji.201344433

190. Gandhi RT, Kwon DS, Macklin EA, Shopis JR, McLean AP, McBrine N, et al. Immunization of HIV-1-infected persons with autologous dendritic cells transfected with mRNA encoding HIV-1 Gag and Nef: results of a randomized, placebo-controlled clinical trial. J Acquir Immune Defic Syndr. (2016) 71:246-53. doi: 10.1097/QAI.0000000000000852

191. Garcia F, Climent N, Guardo AC, Gil C, Leon A, Autran B, et al. A dendritic cell-based vaccine elicits $\mathrm{T}$ cell responses associated with control of HIV-1 replication. Sci Transl Med. (2013) 5:166ra2. doi: 10.1126/scitranslmed.3004682

192. Munson P, Liu Y, Bratt D, Fuller JT, Hu X, Pavlakis GN, et al. Therapeutic conserved elements (CE) DNA vaccine induces strong $\mathrm{T}$ cell responses against highly conserved viral sequences during simianhuman immunodeficiency virus infection. Hum Vaccin Immunother. (2018) 14:1820-31. doi: 10.1080/21645515.2018.1448328

193. Borducchi EN, Cabral C, Stephenson KE, Liu J, Abbink P, Ng'ang'a D, et al. Ad26/MVA therapeutic vaccination with TLR7 stimulation in SIV-infected rhesus monkeys. Nature. (2016) 540:284-7. doi: 10.1038/nature20583

194. Sneller MC, Justement JS, Gittens KR, Petrone ME, Clarridge KE, Proschan MA, et al. A randomized controlled safety/efficacy trial of therapeutic vaccination in HIV-infected individuals who initiated antiretroviral therapy early in infection. Sci Transl Med. (2017) 9:aan8848. doi: 10.1126/scitranslmed.aan 8848

195. Hirao LA, Wu L, Khan AS, Hokey DA, Yan J, Dai A, et al. Combined effects of IL-12 and electroporation enhances the potency of DNA vaccination in macaques. Vaccine. (2008) 26:3112-20. doi: 10.1016/j.vaccine.2008.02.036

196. Luckay A, Sidhu MK, Kjeken R, Megati S, Chong SY, Roopchand V, et al. Effect of plasmid DNA vaccine design and in vivo electroporation on the resulting vaccine-specific immune responses in rhesus macaques. $J$ Virol. (2007) 81:5257-69. doi: 10.1128/JVI.00055-07

197. Sahin U, Derhovanessian E, Miller M, Kloke BP, Simon P, Lower M, Bukur $\mathrm{V}$, Tadmor AD, et al. Personalized RNA mutanome vaccines mobilize poly-specific therapeutic immunity against cancer. Nature. (2017) 547:222226. doi: 10.1038/nature23003

198. Duperret EK, Perales-Puchalt A, Stoltz R, Mandloi N, Barlow J, Chaudhuri A, et al. A synthetic DNA, multi-neoantigen vaccine drives predominately MHC class I CD8(+) T-cell responses, impacting tumor challenge. Cancer Immunol Res. (2019) 7:174-82. doi: 10.1158/2326-6066.CIR-18-0283

199. Rodger AJ, Cambiano V, Bruun T, Vernazza P, Collins S, Degen O, et al. Risk of HIV transmission through condomless sex in serodifferent gay couples with the HIV-positive partner taking suppressive antiretroviral therapy (PARTNER): final results of a multicentre, prospective, observational study. Lancet. (2019) 393:2428-38. doi: 10.1016/S0140-6736(19)30418-0

200. Guaraldi G, Orlando G, Zona S, Menozzi M, Carli F, Garlassi E, et al. Premature age-related comorbidities among HIV-infected persons compared with the general population. Clin Infect Dis. (2011) 53:11206. doi: 10.1093/cid/cir627

201. Maciel RA, Kluck HM, Durand M, Sprinz E. Comorbidity is more common and occurs earlier in persons living with HIV than in HIV-uninfected matched controls, aged 50 years and older: a cross-sectional study. Int J Infect Dis. (2018) 70:30-5. doi: 10.1016/j.ijid.2018.02.009

Conflict of Interest Statement: The authors declare that the research was conducted in the absence of any commercial or financial relationships that could be construed as a potential conflict of interest.

Copyright (c) 2019 Mylvaganam, Yanez, Maus and Walker. This is an open-access article distributed under the terms of the Creative Commons Attribution License (CC $B Y)$. The use, distribution or reproduction in other forums is permitted, provided the original author(s) and the copyright owner(s) are credited and that the original publication in this journal is cited, in accordance with accepted academic practice. No use, distribution or reproduction is permitted which does not comply with these terms. 